\title{
Taxation of Partnership - Economic national reports for the Nordic Tax Research Council's annual meeting, 2015 in Aarhus
}

DOI 10.1515/ntaxj-2015-0008

Received Jul 22, 2015; accepted Sep 18, 2015

\begin{abstract}
This joint report includes economic national reports on the taxation of partnership in the Nordic countries, except Denmark. The general contents of these reports are summarized and thoroughly analyzed in Anna Holst Birket-Smith's General report, published in this issue of the NTaxJ. For additional information, details on legislative measures etc. we find it important, however, to also publish the national reports in full length. We hope you will find it valuable as well. The respective national reports appear in alphabetic order, in regard to the country which regulation is presented. Name of the country reporter and contact information are presented in the beginning of each report.
\end{abstract}

Keywords: Partnership; shared liability partnerships; limited partnerships; internal partnerships; transparent tax entity; Nordic taxation

\section{Finland}

\section{By Matti Kukkonen}

\subsection{Starting remarks}

The multidimensional nature of small business firms sets obviously difficult requirements for the tax system. This fact has also been recognized in Finland. However, it should be noted that the recent Finnish income and company tax reforms have mostly dismissed the specific tax issues of certain small business forms, particularly part-

Axel Hilling (Ed.): Associate Professor, Department of Business Law, Lund University School of Economics and Management, Sweden; Email: axel.hilling@har.lu.se

Matti Kukkonen: Professor, Head of Department, Hanken School of Economics, Helsinki; Email: kukkonen@hanken.fi nerships (in Finnish henkilöyhtiöt, the so-called "person(al)companies”, personbolag).

Small businesses include both self-employed entrepreneurs and partnerships, which are in Finland currently taxed inside the boundaries of individual tax rules (Income Tax Act, taxation of the owners) and also small incorporated firms (small limited companies and co-ops), which are normally taxed separately (tax subjects) from their owners (Business Income Tax Act) as companies ${ }^{1}$. Many economic activities can be carried out either by an employee working for a company or by a self-employed individual. Similarly, many activities can be undertaken either by a self-employed person or by an individual who is the owner. If the tax treatment of the income derived from these activities differs substantially depending on the legal form in which they are conducted, the tax system is likely to have impact on the ways in which small businesses are structured.

It should be noted that the possible asymmetric treatment of profits and losses may affect the tax incentives of partnerships. When taxable profits are positive, they are taxed (as personal income of the owners), but when taxable profits are negative (tax loss situation), they generally do not produce a full tax rebate even though at least partial rebate is possible also in the personal income taxation of the owners. In Finland, the losses are only carried forward ( $\max 10$ years) and there is no compensation for the time delay before they can be used to reduce future tax payments. This implies that the value of future tax reductions associated with an additional 1 euro of tax losses today may be considerably lower than the tax paid on an additional 1 euro of positive taxable profits. This asymmetric treatment of losses can discourage risk taking by firms.

Another fundamental reason why partnerships may present challenges for the tax system is that income derived from small business activities generally reflects a mix of rewards for labor supplied by those who work for the

1 The current details of the Finnish tax system are described and discussed in Järvenoja 2015. 
business and returns to capital supplied by those who invest in the business. With a small, owner-managed company (the basic case in Finland), the owner-partner has considerable discretion over the way in which he/she derives taxable income from the firm. If the partner chooses to pay himself/herself a lower salary, he/she can increase the profits of the firm; and by choosing to distribute these profits, he/she can increase the share of his/her income that comes in the form of dividends.

When the tax treatments of earned income and capital income are different (the situation in Finland), the tax system has a significant impact on the ways in which small business proprietors choose to take their remuneration. If, at the margin, the taxation of distributed profits is lower than the tax rate that applies to labor income, this ability to reclassify income for tax purposes can result in ownerpartners of small firms paying less tax than self-employed individuals or ordinary employees who perform similar tasks for the same gross remuneration. Obviously, in some situations, it may be preferable to transform or reclassify capital income into earned income (wage or something else) if the tax level of capital income (currently nominal rate $30 / 33 \%$ ) is higher than the tax rate on (relatively) small wages.

\subsection{The tax system and the role of partnerships in the Finnish business structure}

As described in Järvenoja (2016), the partnerships are regarded in taxation as nontaxable transparent entities. The partnership as a business firm is not a tax-paying entity. If the owners (partners) are normal Finnish individuals, the partnership income is taxed at the partner level either as capital income at a flat tax rate of 30 or 33 percent or as earned income at progressive tax rates. The distinction between capital and earned income is made on basis of partnership's net wealth (net wealth of business wealth). A 20 percent interest of the partner's share of the partnership's net wealth (imputed rate of return) is determined as capital income and the rest of the share of the partnership income is taxed as earned income. Limited partner's share of the partnership's net wealth is usually determined equal as the capital contribution made by the limited partner. The same income taxation principle is applied also on taxation of the limited partner's income share. Additionally, one very important concept in the Finnish partnership taxation is the asset transfers from partnership to partner's private use (private drawings, privatuttag). A partner can transfer the assets into private use with an amount of more than his or her investments and undistributed profit shares are without triggering taxable income. Thus the partner's equity share can become negative without income taxation. The negativity will be added into capital gain when the partnership interest is alienated or the partner resigns from the partnership.

The legal structure of the Finnish business sector has been relatively stable during the past 15 years (see Statistics Finland and also Kari et al. (2004)). The structure is characterized by the prominent role of incorporated firms. The importance of partnerships has slowly decreased (see also Table 1). The possible dividend tax reform (further increase of partial double taxation of corporate profits) can improve the relative attractiveness of partnerships and sole proprietors compared to corporations.

The Finnish dual income taxation creates directly incentives for income shifting between earned income and capital income (min tax level 0 against 30, max tax level 55 against 33). The current income splitting rules try to control and diminish this kind of tax planning activity. The tax payment of the partner (based on the partnership profit) can be calculated as (see Kari (1998); Kari et al. (2004))

$$
\begin{aligned}
& T=t(c) \cdot(N P), \text { if NP is less or equal than } b \cdot N W \\
& T=t(c) \cdot b N W+t(e) \cdot(N P-b \cdot N W), \\
& N P \text { is more than } b \cdot N W
\end{aligned}
$$

where $T$ is the tax; $t(c)$ is the capital income tax rate (30/33\%); $t(e)$ is the earned income tax rate (0-55\%); $N W$ is the net wealth, the basis of the capital income part of the income; and $b$ is the capital income percent rate (currently $20 \%$ ). With the current numbers, the tax equation is (below income limit 30000 euros)

$$
T=0,3 \times \text { net profit }
$$

Or

$$
T=0,3 \times 0,2 \times N W+t(e) \cdot(\text { net profit }-0,08 \cdot N W)
$$

It should be noted that the NW-variable here includes 30 percent of the paid wages. The capital income tax base increases by wealth and wages ( $0.3 \cdot$ wages). If the partners optimize their net tax situation, they should balance between amount of wages (earned income, can be deducted from the gross profit) and the amount of capital income. Twenty percent of the NW is taxed as capital income. The sole proprietors can choose between 0,10 , and 20 percent, but this option cannot be used by the partners of a partnership.

Additionally, it should be remembered that the (effective) net tax rate of the partner can be decreased by the 


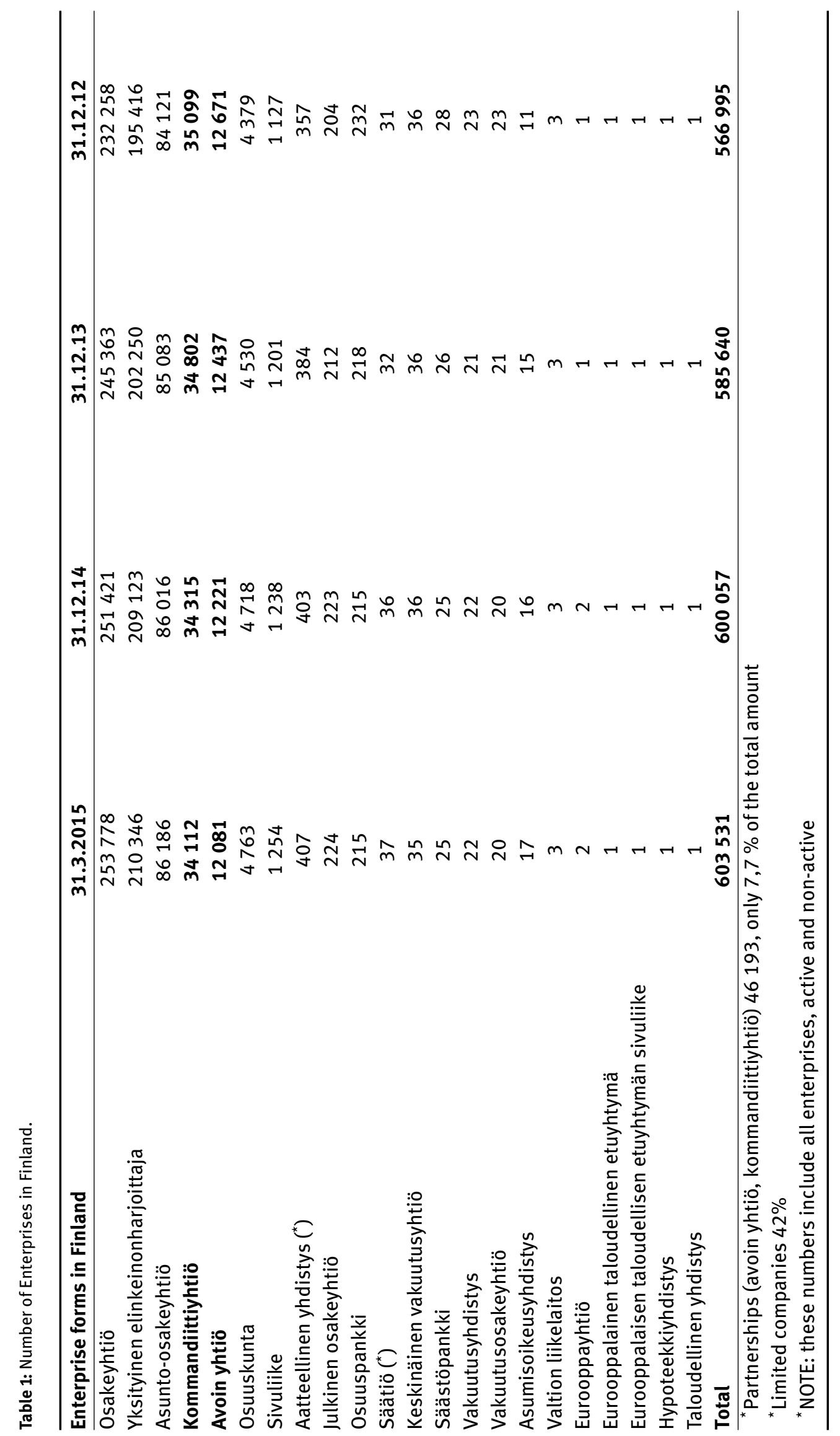


use of operational reserve (toimintavaraus, driftsreservering, 30\%). If the partnership pays out reasonable wages, the reserve can be deducted from the gross taxable income of the firm. There is an incentive to have partner wage payments plus normal personnel wage payments. The tax diminishing effect of operational reserve has been relatively small because of the limited amount of wage payment at the partnerships. In practice, the partners tend to take out the most part of the firm's profit as private transfers (drawings).

The incentive and behavioral effects of tax systems are normally also presented with the help of the cost of capital variable. Based on Kari (1998) and Kari et al. (2004), the firms' cost of capital for investment financed by retained earnings is determined as follows (the basic tax system of partnerships has remained the same for the period 19982015):

$$
p_{P B}=\frac{1-\tau_{k}}{1-\tau_{f}} i-\frac{\tau_{f}-\tau_{k}}{1-\tau_{f}} b
$$

where $t(k)$ is the tax rate for capital income, $t(f)$ is the MTR on earned income, $i$ is the owner's gross rate of return requirement on investment, and $b$ is the rate of return applied in calculating the imputed capital income.

The incentive to transform income can be seen from the second terms on the right-hand side of the formula. If the owner's marginal tax rate on earned income exceeds tax rate on capital income, this tax saving reduces the firm's cost of capital. The formula can be compared with a neutral tax system (same tax level for all business income). If this tax rate would be the capital income tax rate, then we would have tax case $p=i$. If we have equation level $b=i$, the tax system of partnerships is neutral toward investments. With higher marginal tax rates, the partners have incentive to invest if gross rate of investment is less than $b$. In Finland, the imputed rate of return is currently $20 \%(0,20)$.

\subsection{The current tax reform debate and some predictions around the Finnish SMEs}

Twenty years ago, the taxation of partnerships was pondered actively in the Finnish tax reform debate. But afterwards, the tax reform debate has only touched the closely held corporations. The Finnish tax debate seems to provide (on general level) more active tax reform plans better tax terms for small limited companies than for the nonincorporated firms. The sole proprietors and partnerships may, however, get a specific entrepreneur tax allowance (extra tax deduction from the business income, $5 \%$ of the taxable net income, the current tax reform plan) but this is at this point only an option. It seems that the planned new tax allowance will not be a part of tax legislation for the next year (2016). The basic system (taxation of partners, not the firm) continues as earlier.

\section{Bibliography}

Järvenoja, Markku, Finish Legal Report, in Hilling, Axel (Ed), Taxation of Partnership - Legal national reports for the Nordic Tax Reserach Council's annual meeting, 2015 in Aarhus, Nordic Tax Journal, Vol. 2015, Issue 2, 2016

Kari, Seppo; Karikallio, Hanna; Rauhanen, Timo; Kröger, Outi, Beskattning av småföretag i Finland, VATT Discussion Papers 332, 2004

Kari, Seppo; Rauhanen, Timo; Kröger, Outi, Henkilöyhtiöiden verotuksen investointi- ja työllistämiskannustimet, VATT Research Reports 49, 1998

\section{Iceland}

By Linda Garðarsdóttir

Abstract: This article aims to describe the partnership forms in Iceland from an economic point of view. First, there is a short description of the most common forms of entities in Iceland and their structure. The emphasis will be on general partnership, limited partnership, and partnership limited by shares. Second, there is a description on the development of the corporate, partnership, and personal income tax rates. Third, statistics on total number of partnership forms, including independent tax entities and transparent tax entities, are introduced along with figures on the tax base and sector analysis. Fourth, an overview on different taxation between various forms of entities and the pros and cons of choosing a certain legal form for a business. Finally, the main conclusions are summed up.

Keywords: General partnership; limited partnership; partnership limited by shares; transparent tax entity; independent tax entity; tax incentives

Linda Garðarsdóttir: Economist, Icelandic Ministry of Finance and Economic Affairs, Iceland; E-mail: linda.gardarsdottir@fjr.is 


\subsection{Introduction}

There are two tax registries in Iceland, that is, the registry for individuals and the registry for legal entities. The Directorate of Internal Revenue is responsible for the operation of both registries.

The registry for individuals contains all individuals older than 16 years of age, where all individuals who are self-employed are included. Their total number has increased considerably in recent years and in 2013 was $268,451^{2}$. The number of self-employed was 15,581 , but those are individuals who have some sort of business in their own name and ID number ${ }^{3}$. Only a part of those show a business profit and pay income tax accordingly.

In the tax registry for legal entities are companies who can either be taxable or non-taxable. In 2013, the total number of companies in the first group was 38,123 and in the latter group 15,811. In total, there were 53,934 legal entities in the tax registry in 2013 and their number has been increasing for the last years. Not all businesses are profitable, but in 2013, about $42.2 \%$ of the companies paid income tax. Some forms of entities in the tax registry offer a choice regarding the tax structure when establishing a company, whether to be taxed independently or to be a transparent tax entity. This applies, for example, to those who establish general partnership, limited partnership, and partnership limited by shares. In the year 2013, there were 573 partnerships registered as transparent tax entities compared with 3234 partnerships as independent tax entities.

The most common forms of legal entities are public limited company, private limited company, self-employed entity, general partnership, limited partnership, and partnership limited by shares, where the most popular one is private limited company. Owner's responsibility and tax structure varies between the forms, as well as regulations on accounting and registration.

What follows is a short description of the most common forms of entities in Iceland and their structure. The emphasis will be on general partnership, limited partnership, and partnership limited by shares. Second, there is a description on the development of the corporate, partnership, and personal income tax rates. Third, statistics on total number of partnership forms, including independent tax entities and transparent tax entities, are introduced along with figures on the tax base and sector analy-

2 Estimated population was 321,857 at year end 2013.

3 Those who have declared imputed salaries as a part of their yearly tax return. sis. Fourth, an overview on different taxation between various forms of entities and the pros and cons of choosing a certain legal form for a business. Finally, the main conclusions are summed up.

\subsection{Forms of entities}

\subsubsection{Self-employed entity}

A self-employed entity is a business form where one party owns and runs a business in his own name and ID number where the owner's responsibility on the company's commitments is direct and unlimited. Direct responsibility means that creditors can access the owner's total assets if debts are not paid. Self-employed entities pay personal income tax and the amount depends on the income earned with three brackets ranging from 37.3 to $46.24 \%$. The owner has to return an operating account along with the yearly tax return which details the entities' income and expenditure including the owner's minimum imputed wage. No taxes are paid when the profit is paid out. There is no need to register a self-employed entity in a company registry unless the business is to be given a specific name that is other than the owner's name.

\subsubsection{Public Limited Company}

The owners of public limited companies need to be at least two and their indirect responsibility is limited to their contribution of equity to the company. The equity needs to be at least 4 million ISK. Public limited companies are independent tax entities and pay $20 \%$ corporate income tax. Dividends paid out to owners are subject to capital income tax, which is presently $20 \%$, but there are special regulations that limit dividend payments. Public limited companies are listed in the company registry operated by the Directorate of Internal Revenue.

\subsubsection{Private Limited Company}

A private limited company can have one or more equity owners and their responsibility is limited to their equity share in the company. The minimum equity is 500,000 ISK. Private limited companies are independent tax entities like the public ones and pay $20 \%$ corporate income tax. Dividends paid out to owners bear $20 \%$ capital income tax, but there are special limited rules on dividend payments. They are also listed in the company registry. Private limited 
companies, being the most popular business form in Iceland, do not have as strict legal framework as public limited companies and are therefore better suited for smaller businesses where the intention is not to attract public investors.

\subsubsection{General Partnership}

General partnerships need to have at least two owners that can either be an individual or a legal entity. All owners bear direct, undivided, and unlimited liability of the company's commitments. General partnerships can choose to be independent tax entities and if that is the case, they bear 36\% partnership tax. They can also be transparent tax entities, but then the owners are taxed by their share in the partnership and the tax percentage is the same as for a self-employed entity (37.3-46.24\%). If the owner is a legal entity, then the $20 \%$ corporate income tax applies. No additional tax is levied on the partnership's profit when paid out. All general partnerships are registered in the company registry.

\subsubsection{Limited Partnership}

Limited partnerships have one or more partners with direct, undivided, and unlimited liability for the partnerships' liabilities and one or more partners with limited liability that is limited to their share of the equity. Those partners therefore do not bear more liability than they put in the company just as shareholders in limited companies. Limited partnerships can be independent or transparent tax entities with either $36 \%$ partnership tax or taxed by their share in the partnership with steps from 37.3 to 46.24\% personal income tax (if the partner is an individual), or $20 \%$ corporate income tax (if the partner is a legal entity). As with general partnerships, no additional tax is levied on the partnership's profit when paid out. All limited partnerships are registered in the company registry.

\subsubsection{Partnership Limited by Shares}

Partnership limited by shares are, like limited partnerships, required to have one or more owners with direct, undivided, and unlimited liability on the company's commitments and one or more owners with limited liability based on each and everyones share of the equity. Minimum equity is 4 million ISK. Partnerships limited by shares can be independent tax entities where the corporate income tax is $20 \%$ or transparent tax entities where the partners are taxed by their share in the partnership (37.3-46.24\% / $20 \%$ ). Dividend is paid out in accordance with regulations. Presently, the capital income tax is $20 \%$. All partnerships limited by shares are registered in the company registry.

\subsection{The development of corporate, partnership, and personal income tax rates}

Figure 1 shows the development in the corporate income tax rate and the partnership income tax from 1990 to 2015 as well as capital income tax rate from 1997. There has been a large change in both corporate and partnership income tax rates since 1990 . Both tax rates gradually decreased until 2008 with the goal of improving the competitiveness of Icelandic companies and attracting foreign investment. After the financial crisis hit Iceland in 2008, the tax rates have increased a little again with more drastic increase in the tax rate for partnership mainly due to the increase of the capital income tax rate from 10 to $20 \%$. The corporate income tax rate was raised from 15 to $18 \%$ in 2010 and to $20 \%$ in 2011 . The partnership income tax rate was also raised from 24 to $33 \%$ in 2010 and to $36 \%$ in 2011.

For transparent taxable entities owned by individuals, Figure 2 shows the development in their tax rates (personal income tax). From 1993 to 2005, the income tax rate decreased, but at the same time, a special income tax was introduced on revenues above a certain threshold. In 2006, the special income tax was abolished altogether for 3 years, but became effective again for the last 6 months of 2009. As a consequence of the financial crisis, a personal income tax with three brackets was introduced in 2010 in order to collect more revenues. In 2014, the rates were altered a little between the brackets increasing the last bracket and decreasing the other two. Presently, the

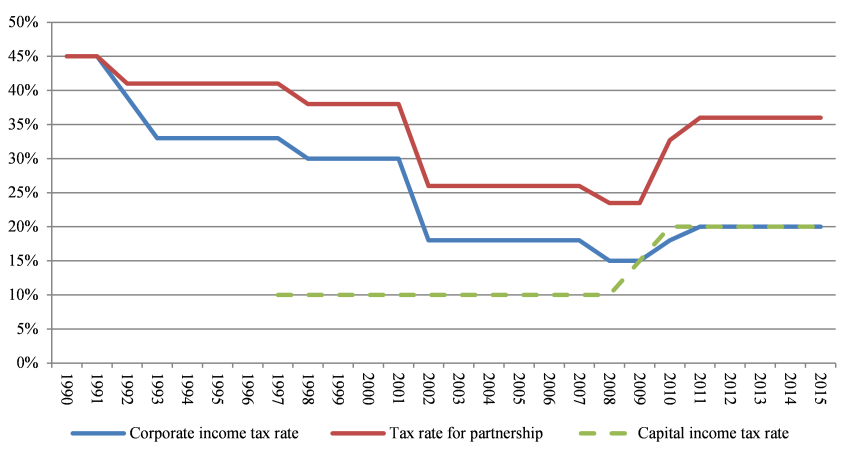

Source: Directorate of Internal Revenue

Figure 1: Corporate, partnership, and capital income tax rates. 


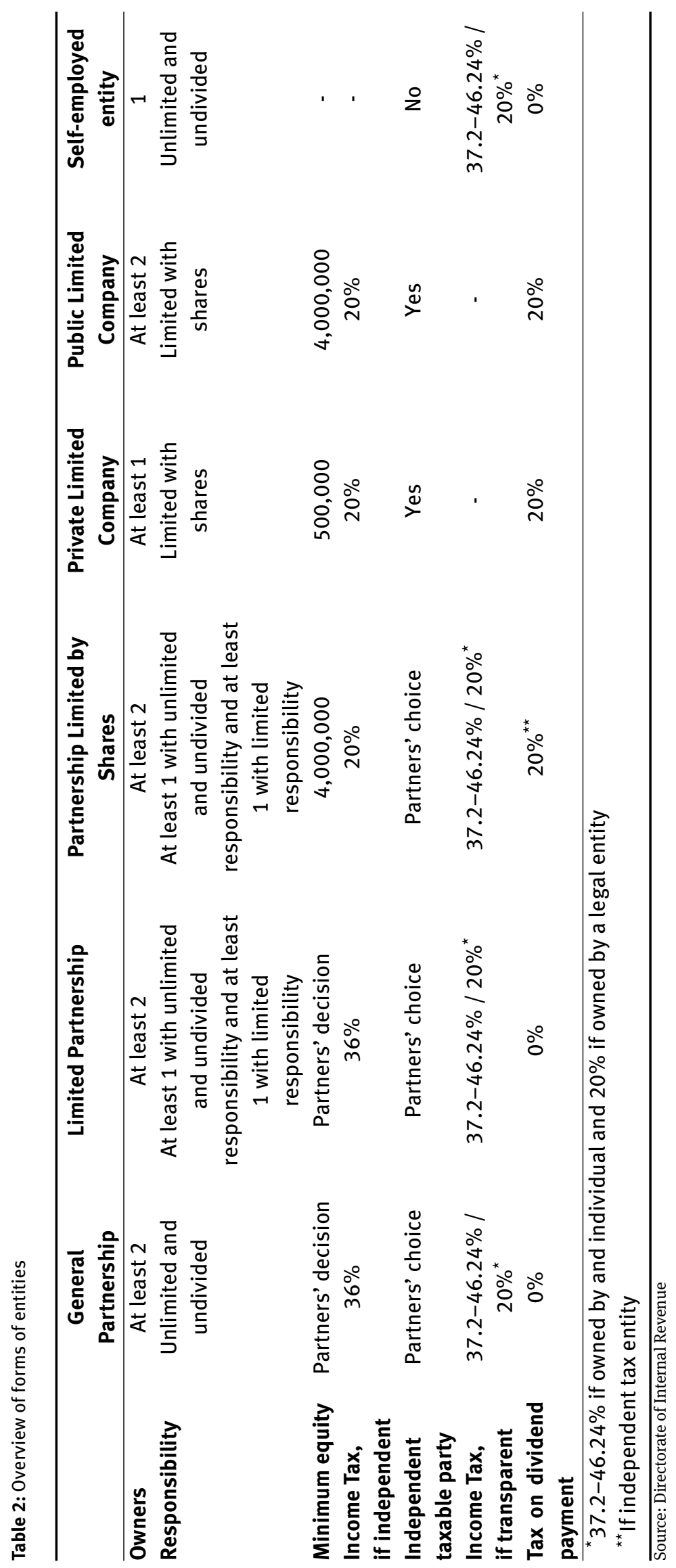


personal income tax is levied by three brackets, that is, $37.3 \%$ income tax on revenues up to ISK 309,140 per month, $39.74 \%$ on revenues between ISK 309,140 and ISK 836,404 per month and $46.24 \%$ on revenues above ISK 836,404 per month.

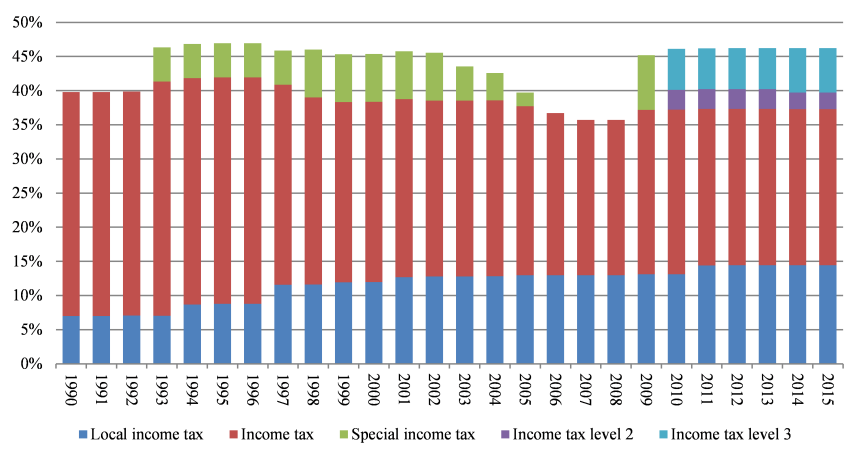

Source: Directorate of Internal Revenue

Figure 2: Personal income tax rates

\subsection{Statistics}

The data is collected from the tax registry of legal entities for the years 2006-2013. All legal entities are registered there, both the independent and transparent tax entities. Information on transparent tax entities is, however, difficult to obtain. It was, for example, not possible to obtain information on the tax base and the returns. These types of partnerships fill in their tax assessments within the owners' private ones and often do not fill out extra forms with all appropriate information to be able to know for certain the relevant data. It was also impossible to publish data showing its share of returns in proportion of the tax bases for partnerships with independent tax entities. Companies in the partnership forms are very few in Iceland, thus, one or two companies can confuse the whole picture. Nevertheless, the published data should give a fairly broad picture on the structure of the forms of entities.

\subsubsection{Number}

As mentioned before, the partnership forms can be divided into either independent or transparent tax entities. The former one is more common with, for example, 1509 general partnerships with independent tax entities and 487 with transparent tax entities in 2013. With 1996 general partnerships in total, it becomes the most popular partnership form in Iceland. The number of general partnerships has been relatively stable over the past years with a little decrease since 2006.

The number of limited partnerships has increased dramatically since 2009 or by $219 \%$. That is mainly a result of change in the legislation for limited companies in 2009 (called 20/50 rule). According to the law, dividend up to $20 \%$ of equity could be taxed as capital income. Half of dividend payment exceeding $20 \%$ of equity was taxed as salaries and half as capital income. This change in the legislation affected private limited companies significantly. Previously, it was not as popular to establish a company within the limited partnership form because at least one owner had an unlimited responsibility of the company's commitments. With the new legislation that changed, establishment of limited partnership increased a lot and many private limited companies were changed to a partnership form. The reason being that in partnerships, there are no taxes on dividend payments, thus, the profit goes directly to the owners. As a result, partnerships' tax burden was less than the tax burden of limited companies. In 2013, the legislation was abolished. One issue that came up regarding the rule is that some avoided taking on the responsibility issue by establishing a private limited company as well and by making it a co-owner of the limited partnership and bearer of the unlimited responsibility. As a result, the original owner(s) then only had a limited responsibility. Whereas the owner of a private limited company has a limited responsibiliy, none is fully responsible for the commitments of the limited partnership. Now, limited companies only need to pay capital income tax on all dividend payments as they did before the change in the law. The number of limited partnerships was 1712 in 2013 where $97 \%$ were independent tax entities and 3\% transparent tax entities.

The number of partnerships limited by shares has been increasing over the past 9 years, but is still few in comparison with the other group forms. In 2013, they totaled 53,

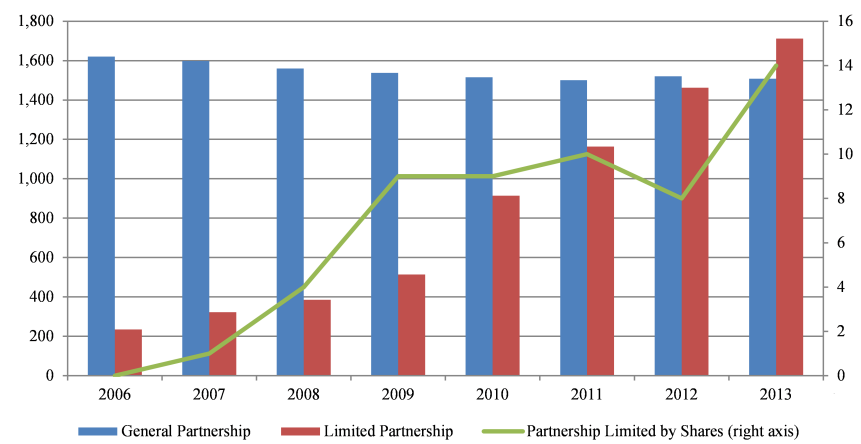

Source: Directorate of Internal Revenue

Figure 3: Number of independent tax entities. 
Table 3: Total number of companies in 2013.

\begin{tabular}{cccccccc}
\hline & $\begin{array}{c}\text { General } \\
\text { Partner- } \\
\text { ship }\end{array}$ & $\begin{array}{c}\text { Limited } \\
\text { Partner- } \\
\text { ship }\end{array}$ & $\begin{array}{c}\text { Partnership } \\
\text { Limites by } \\
\text { Shares }\end{array}$ & $\begin{array}{c}\text { Self- } \\
\text { employment }\end{array}$ & $\begin{array}{c}\text { Private } \\
\text { Limited } \\
\text { Company }\end{array}$ & $\begin{array}{c}\text { Public } \\
\text { Limited } \\
\text { Company }\end{array}$ & Total \\
\hline Independent tax entity & 1,509 & 1,712 & 14 & - & 33,604 & 733 & 37,572 \\
Transparent tax entity & 487 & 48 & 39 & 15,581 & - & - & 16,155 \\
Total & 1,996 & 1,760 & 53 & 15,581 & 33,604 & 733 & 53,727 \\
\hline Source: Directorate of Internal Revenue & & & & & & &
\end{tabular}

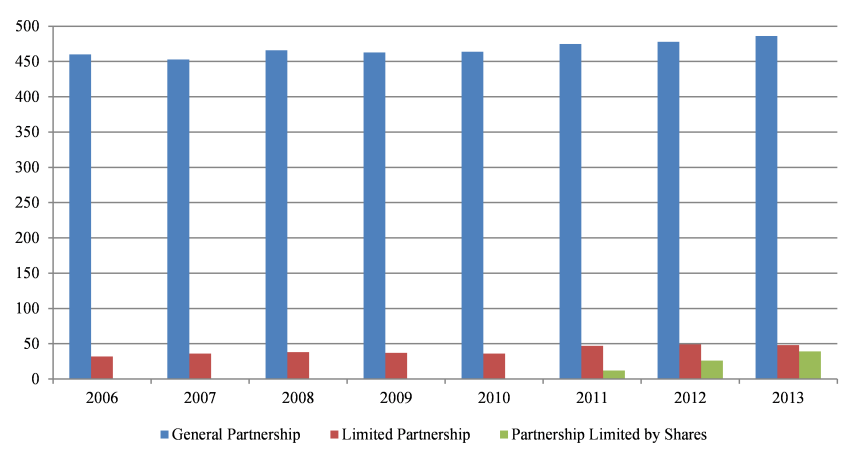

Source: Directorate of Internal Revenue

Figure 4: Number of transparent tax entities.

including 39 with transparent tax entities, after being almost nonexistent before 2006.

The most common business form in Iceland is a private limited company with 33,604 companies in 2013. It has increased by $28 \%$ since 2006 , but only by $0.7 \%$ from 2012-2013. At the turn of the century, it became popular to establish private limited companies. The corporate income tax rate was much lower than the personal income tax rate and the capital income tax rate (which came into effect in 1997) was also very low or $10 \%$. As a result, the number of companies in this form increased dramatically at the expense of self-employed entities. The ratio between

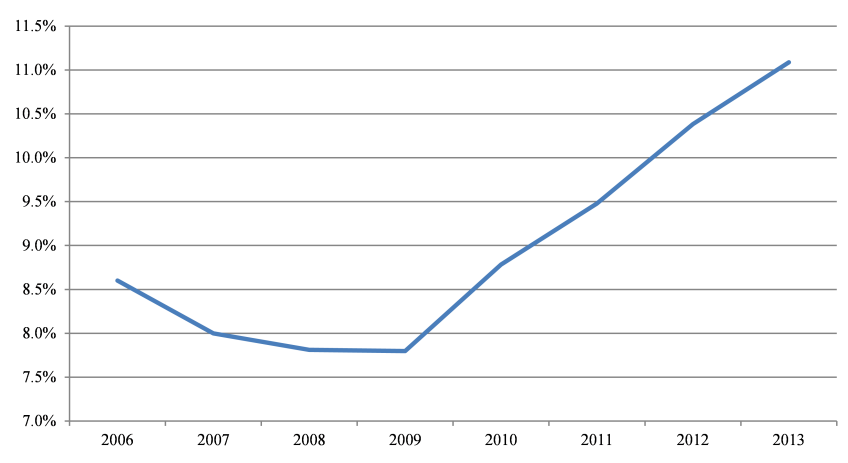

Source: Directorate of Internal Revenue

Figure 5: Ratio between the partnership forms and the liability companies. partnership forms (independent and transparent tax entities) and liability companies (private and public) has been increasing after the financial crisis, both because the latter ones increased at a slower pace and limited partnerships increased sharply at that time, as discussed earlier due to the 20/50 tax rule. In 2013, the ratio was $11.1 \%$ compared with $10.4 \%$ the year before after being down to $7.8 \%$ in 2009.

\subsubsection{Sector analysis}

The number of partnership forms divided by sectors is presented in Figure 6. Most partnerships, both in general and limited partnership forms, are in the sector of professional, scientific and technical activities with a total of 716 partnerships. Included there are, for example, lawyer services, accountants, architects, and engineering businesses and advertising agencies. The second biggest sector for these forms is human health and social work activities followed by constructions. However, almost all partnerships limited by shares are in financial and insurance activities or 42 out of 53.

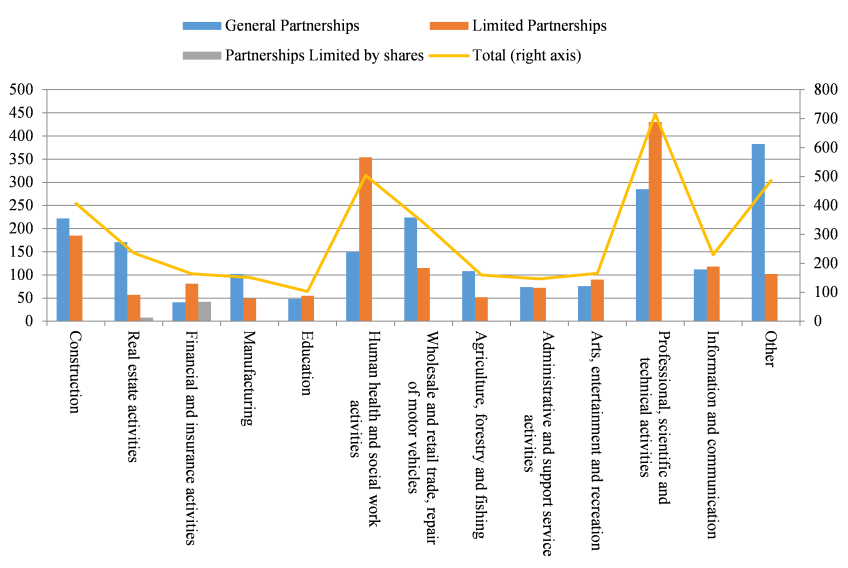

Source: Directorate of Internal Revenue

Figure 6: Sector analysis. 
Table 4: Taxation on a wage earner and a self-employed person ${ }^{4}$

\begin{tabular}{lcccc}
\hline & Wage-earner & Self-employed & $\begin{array}{c}\text { Transparent } \\
\text { Partnership }\end{array}$ & $\begin{array}{c}\text { Independent } \\
\text { Partnership }\end{array}$ \\
\hline Salaries & $1,000,000$ & - & - & - \\
Taxes & 400,491 & - & - & - \\
Profit & - & $1,000,000$ & $1,000,000$ & $1,000,000$ \\
Taxes & - & 400,491 & 400,491 & 360,000 \\
After Tax & $\mathbf{5 9 9 , 5 0 9}$ & $\mathbf{5 9 9 , 5 0 9}$ & $\mathbf{5 9 9 , 5 0 9}$ & $\mathbf{6 4 0 , 0 0 0}$ \\
\hline Source: Own calculations & &
\end{tabular}

\subsubsection{Tax base for independent tax entities}

The total tax base for partnerships in the form of independent tax entities has been increasing for the last 3 years mainly because of a sharp increase in the tax base of limited partnership forms. However, the tax base for partnerships limited by shares has been almost zero for all the years in question, which is a result of a low profit and high losses carried forward. After the financial crisis, the tax base for all forms were weaker except for limited partnerships, but it has been improving again for the last few years. The tax rate for all forms also increased in 2010 and 2011 that helped the tax base to recover after the crisis.

In total, the proportion of partnerships' tax base and the tax base of limited companies was $4.9 \%$ in 2013. The ratio has increased since the financial crisis because, at that time and the years thereafter, losses increased in the annual accounts, especially for public limited companies, and therefore there was no income tax base for some of

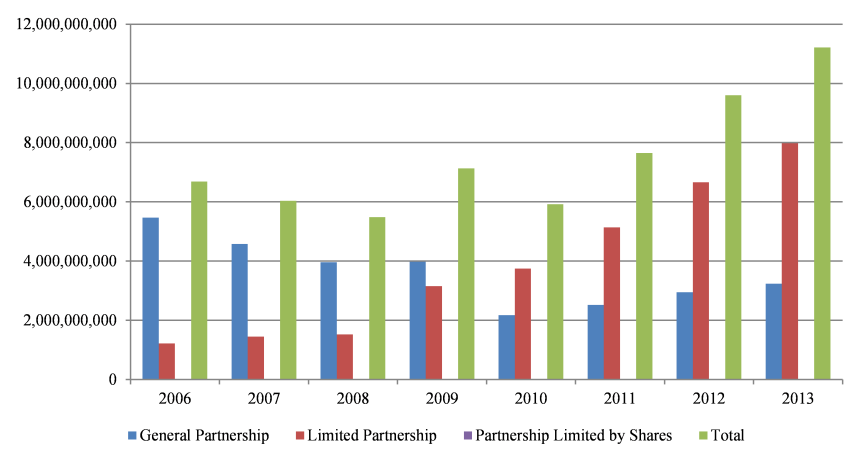

Source: Directorate of Internal Revenue

Figure 7: Tax base of partnerships with independent tax entities.

4 Minimum imputed wages are not shown specifically in this example for the self-employed person and the owners of the partnerships. It has already been taken into account in the profit. Also, if there would be a deficit on the company, no taxes would be paid except personal income tax on the minimum imputed wage. the companies. Many companies also became bankrupt or have ceased to operate, thus, the number of public limited companies is less now than before 2008. In recent years, the main increase has also been in the establishment of limited partnerships in expense of private limited companies, which increases the tax base for the partnerships.

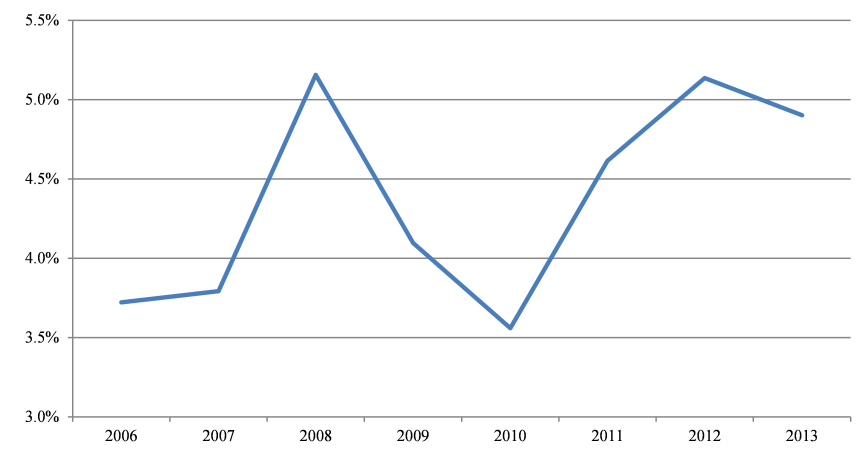

Source: Directorate of Internal Revenue

Figure 8: Ratio between the tax base of partnerships and limited companies.

\subsection{Choosing the right form of entity}

The right form of entity for a company can be difficult to choose and it is necessary to take account of other things than the difference in taxation between the forms, for example, things like the difference in responsibility and what the overall activity of the company is going to be.

Minimum imputed wages for self-employed, partnerships, and limited companies are published each year by the Directorate of Internal Revenue. Principals should allocate to themselves the appropriate minimum wage in all three types of business, upon which they pay personal income tax, social security contribution, and premium to the pension funds. Minimum imputed wages are not supposed to be lower than if it were salaries received working for an 
unrelated person. The same applies to minimum imputed wage for work of spouses, own children under 16 years old, in-laws or close relatives.

In some cases, it is possible to choose from being a self-employed or a wage earner. A self-employed person is taxed as an individual. The tax base is the owner's total revenue, both professional operating income and other private revenues, which are not related to the business less operating expenses. It is permitted to withdraw some business expenses from the revenues, for example, minimum imputed wage. As a self-employed person is taxed with the same tax rates as a wage earner, there is no difference in the tax payments for a self-employed person with a profit of ISK 1 million and an individual with salaries of ISK 1 million. The same is also relevant for a partnership with a transparent tax entity. Thus, there are no tax incentives between these forms. However, a partnership with an independent tax entity pays less tax of the profit whereas the tax rate is lower, or $36 \%$ instead of $37.3-46.24 \%$.

After the financial crisis in 2008, the Icelandic government requested the International Monetary Fund (IMF) to conduct a review of the tax system. The outcome of the review was published in two reports, in June 2010 and May 2011. According to the IMF, the allocation of capital and labor income should be the same for self-employed, partnerships, and private corporations, so that the form of business does not depend on tax considerations. At least, the method should be unified for partnerships and corporations, since self-employed have the option of adopting one of these forms if they have significant capital assets (2011, 22).

There can be a tax incentive between a transparent partnership and a limited company even though it is not between the latter one and a partnership with independent tax entity. As discussed before, the tax rate for a partnership form with independent tax entity is $36 \%$. For a partnership with a profit of ISK 100, the tax payment is therefore ISK 36. There is no tax payment on the profit paid out. Thus, the owner can take the after tax amount out of the company without paying additional taxes. For limited companies, the income tax rate is $20 \%$. If the profit is ISK 100 , the income tax paid is ISK 20. If the owner takes the after tax amount (ISK 80) out of the company, a payment of $20 \%$ capital income tax is needed or ISK 16 . The total tax paid is therefore ISK 36, the same amount as owner of a partnership has to pay $^{5}$. Hence, there are no tax incentives between partnership forms with an independent tax entity and liability companies. The difference lies in other

$536 \%(=0.20+(1-0.20) \cdot 0.20)$.
Table 5: Taxation on partnerships and a limited company.

\begin{tabular}{lccc}
\hline & $\begin{array}{c}\text { Independent } \\
\text { Partnership }\end{array}$ & $\begin{array}{c}\text { Limited } \\
\text { company }\end{array}$ & $\begin{array}{c}\text { Transparent } \\
\text { Partnership }\end{array}$ \\
\hline Profit & 100 & 100 & 100 \\
Taxes & 36 & 20 & 37.3 \\
Dividend & 64 & 80 & 62.7 \\
Taxes & 0 & 16 & 0 \\
Total & 36 & 36 & $\mathbf{3 7 . 3}$ \\
taxes paid & & & \\
\hline
\end{tabular}

Source: Own calculations

parts, for example, the responsibility and minimum equity needed. The favorable tax regime for corporate profits and partnership income relative to labor income has, however, created incentives to move from self-employed over to private limited and partnership companies with independent tax entity. Also, for a partnership with transparent tax entity, the income tax rate is between 37.3 and $46.24 \%$ depending on the amount of the profit. Thus, that kind of a form pays higher taxes than partnership with independent tax entity and limited company.

\subsubsection{Pros and cons}

All business forms of entities have their pros and cons. Some are more convenient for smaller companies, others for larger ones. Choosing a form can also depend on the debt structure of the company and its financing.

A general partnership can be a good form if there is no or very little debt in the company and the business has a low risk. The starting cost can be low whereas the startup capital is decided solely by the owners and there are less compulsory legal rules and restrictions than for limited companies. General partnerships do not need to pay capital income tax of the profit allocation and is therefore more flexible form than public and private limited companies. However, the owners' risk is very high since they are responsible for the company with all their assets. Hence, this form could be good if the owners' cooperation is good and filled with trust and the business is a low risk and profitable.

Limited partnership is similar to a general partnership except there is only one owner needed to take responsibility of the business with all its assets. The startup capital is again decided by the owners with no minimum. The profit of the company can go directly to the owners without paying capital income tax. It can be quite risky to be the one who bears full responsibility of the company's com- 
mitments, therefore the owners need to work well together, the business cannot have high risk or it has to have low debts and it needs to be profitable.

The only difference between general and limited partnerships with independent tax entities vs. transparent tax entities is the income tax rate, which is higher for the latter. That explains why there are very few partnerships that are transparent compared with the independent tax entities. Nonetheless, some could find it easier to hand in one individual tax assessment and do not want to do a seperate one for the company. It could also be the case that two people start a partnership together to be able to advertise its business as a group and have a logo for the company, but nevertheless, want to be on their own as if they were self-employed.

Partnership limited by shares is not a very common form. It is a mix of a limited partnership and a limited company. The startup capital is high, the rules are more complex than in other partnership forms, and it is not possible to take all the profit out of the company without paying taxes. However, it could be convenient to establish a company under this form if it is a company engaged in, for example, research and development. One of the owners could be responsible for the commitments and would also bring in the knowledge (e.g. biotechnologist) and the other (shareholder) brings in the finance. Still, the ownership could be $50 / 50$.

Responsibility for the company's commitments is low in private limited companies. The only risk is to lose the amount of capital put into the company. It is also easier to sell this kind of a company compared with a partnership. However, this form is less flexible than the partnership forms. The owners might not be able to take as much as they want out of the company and they always need to register it as dividends or salaries.

In a public limited company, the owner's responsibiliy is low and only depends on the amount of money put into the company by buying shares in it. It is easier to sell this form than the partnership form. Also, a public limited company can get new funding by increasing its stocks. Nonetheless, the rules are very strict for public limited companies and there is much surveillance for companies listed in the stock market. The startup capital is also high and the owners cannot allocate the profit as they want. A confirmation on whether the company can pay any dividend is needed from a stockholder's meeting.

Self-employed entity can be suitable if the company has a low risk. The owner is independent in its decisions, there is no startup capital, and it is not necessary to list it in a company registry. It is also possible to use operating cost to lower operating revenues and there is no capital in- come tax paid on the allocation of the profit. Nonetheless, this form is quite risky for the owner because his responsibiliy is both unlimited and undivided. Hence, the owner is responsible, with all his assets, for the business. The income taxes are high and it can be more difficult to sell the business.

\subsubsection{Financing}

All types of partnership forms and limited companies can normally get a loan from a bank if the owners provide some equity themselves. The bank also has to approve the business model and be convinced that the business can pay the loan back. Nonetheless, if the owner cannot provide equity, it can be possible to provide collateral in their houses or some insurance for the loan. The most common type that banks lend to is private limited company. It is also possible to get a venture capital from the NSA ventures, a fund which emphasizes on startup companies with high growth potential. However, it only invests in limited companies or partnerships limited by shares with the most common setup being again, private limited company. If the fund has been invested in a company, it might be possible to get a loan from them as well.

\subsection{Conclusion}

There is no special political focus on any business form of entity, including partnership forms in Iceland. In 2010, new law came into force that grants support to innovation companies with the goal to strengthen research and development and improve the competitive conditions for innovation companies by offering them tax deduction due to cost on innovation projects. The law does, however, only apply to partnerships with independent tax entities and limited companies, but not partnerships, which are transparent tax entities. The main conclusions from this article on the partnership forms in Iceland are following:

- It is more popular to establish a partnership with independent tax entity than partnership, which is a transparent tax entity.

- The most popular partnership form in Iceland is general partnership followed by the increasing numbers of limited partnerships.

- As a result of a special rule called 20/50 rule, which was in force in 2009-2013, the number of limited partnerships increased significantly. 
- The data on partnerships, which are transparent tax entities, are difficult to obtain, for example, the tax base and return, therefore they are not included in this report.

- There are no tax incentives between a wage earner and a self-employed person with the same amount of salaries and profit.

- There are no tax incentives between partnerships with independent tax entities and limited companies, however, there is more tax burden on partnerships, which are transparent tax entities.

- There are other parts apart from taxation that can affect what kind of a form is chosen for a company, for example, responsibility on the company's commitments, minimum equity needed, and the overall activity the company will be engaged in.

\section{Bibliography}

IMF (International Monetary Fund). 2010. “Improving the Equity and Revenue Productivity of the Icelandic Tax System”.

IMF (International Monetary Fund). 2011. “Advancing Tax Reform and the Taxation of Natural Resources".

NSA ventures. 2015. The Leading Icelandic Venture Capital Fund. http://www.nsaventures.is/About/. Accessed 13 March 2015.

Nýsköpunarmiðstöð Íslands. 2015. Einkahlutafélög og hlutafélög. http://nmi.is/studningur/ad-hefjast-handa/form-fyrirtaekja/ einkahlutafeloeg-og-hlutafeloeg/. Accessed 9 February 2015.

Nýsköpunarmiðstöð Íslands. 2015. Sameignarfélög. http: //nmi.is/studningur/ad-hefjast-handa/form-fyrirtaekja/ sameignarfeloeg/. Accessed 9 February 2015.

RSK (Ríkisskattstjóri). 2015. Einkahlutafélög. https://www.rsk.is/ fyrirtaekjaskra/stofnun-felaga/einkahlutafelog/. Accessed 2 February 2015

RSK (Ríkisskattstjóri). 2015. Hlutafélög.https://www.rsk.is/ fyrirtaekjaskra/stofnun-felaga/hlutafelog/. Accessed 2 February 2015.

RSK (Ríkisskattstjóri). 2015. Reiknad endurgjald 2015. https://www.rsk.is/atvinnurekstur/stadgreidsla-og-reiknadendurgjald/reiknad-endurgjald/2015. Accessed 10 March 2015.

RSK (Ríkisskattstjóri). $2015 . \quad$ Sameignarfélög. https://www.rsk.is/fyrirtaekjaskra/stofnun-felaga-iatvinnurekstri/sameignarfelog/. Accessed 2 February 2015.

RSK (Ríkisskattstjóri). 2015. Samlagsfélög. https://www.rsk.is/ fyrirtaekjaskra/stofnun-felaga-i-atvinnurekstri/samlagsfelog/. Accessed 2 February 2015.

\section{Norway}

By Andrea Papini and Thor O. Thoresen

\subsection{Introduction}

Entrepreneurship, innovation, and job creation are muchcelebrated phrases of the modern economy. Politicians strive to encourage entrepreneurship, and one important subgroup of entrepreneurs is the self-employed, selfemployment is often promoted and celebrated. Given this, it is surprising to find that knowledge of the behavior of the self-employed often is deficient, which is admittedly the case in Norway too ${ }^{6}$. According to Parker (2004), selfemployment and entrepreneurship is sadly neglected in economics textbooks. There might be several reasons for this, but we believe Parker's (2004) notion on economists' "inability to pigeon-hole this multifaceted issue" has some relevance.

Even though there is a focus on the self-employed as an entrepreneur, one should stress that the self-employed are a diverse group of people, including business proprietors, independent professionals (such as lawyers, doctors, and dentists), owners of local grocery stores, subcontractors (such as construction workers), and farmers. As we shall soon see, the self-employed are relatively few in Norway, compared to what is seen in many other economies. However, as the dual income tax schedule involves taxing capital and labor income at different rates, and as splitting different tax bases for the owner of a small businesses bring the practical challenges up to the surface, taxation of sole proprietors and partnerships have been at the center of Norwegian tax policy discussions in the past decades.

The tax reform of 1992, which introduced a version of the dual income tax in Norway, introduced the so-called "split model" to separate income into labor and capital parts for the self-employed, active owner of partnerships, and other closely held firms (defined as businesses in

\footnotetext{
Andrea Papini: Ph.D. Student, Oslo Fiscal Studies, Department of Economics, University of Oslo, Norway; Email: andrea.papini@econ.uio.no

Thor 0. Thoresen: Senior Researcher, Statistics Norway and Oslo Fiscal Studies, Department of Economics, University of Oslo, Norway; Email: thor.olav.thoresen@ssb.no

6 Recently, there have been some attempts to study the entrepreneurship phenomenon in Norway, see Berglann et al. (2011) and Raknerud and Van Praag (2014). However, these papers do not consider the relation between taxation and self-employment.
} 
which more than two-thirds of the shares were owned by the active owner). It can be argued that the Norwegian tax reform of 1992 was revised in 2006 primarily because the post-1992 system failed to deliver equal tax treatment of business owners who have chosen different organizational forms for their business activities.

In the following, we shall take closer look at the taxation of owners of small businesses. This paper is organized as follows. In Section 2, we shall briefly discuss the role of the self-employed in the Norwegian economy. Then, in Section 3, we describe the background for the present Norwegian tax system of small businesses. Further, in Sections 4 and 5, we shall discuss self-employment in a public economics context, mainly focusing on incentives following from differences in taxation of the self-employed, wage earners, and other organizational forms. In Section 6 , we discuss some efficiency aspects of the Norwegian tax schedule, whereas recent trends in self-employment and participation in partnerships are discussed in Section 7. Section 8 concludes the paper.

\subsection{The self-employed as part of the economy}

There are substantial problems in the categorization of people with respect to occupational status. A basic question is: should occupational status be determined by the perceived and reported status of the individual or should it rather be classified as the individual's main activity as seen in data? If one chooses the latter, how does one then define main activity? By the occupation where the individual generates most income or where he spends most time? In regular dependent jobs, wage income is usually proportional to working hours, but that need not be the case in self-employment.

With respect to the economic impact of selfemployment, Stambøl (2010) found that self-employment share of the workforce is approximately 8 percent. In terms of income shares, some simplified calculations based on income statistics (Statistics Norway (2014a)) suggest that approximately 4-5 percent (measured both at the household level and at the individual level) of total (gross) income comes from business income.

Further, according to Parker (2004), the nonagricultural self-employment rate $^{7}$ in Norway fell from 10.1 per-

7 Measured as the proportion of the work force. cent in 1960 to 4.8 percent in $2000^{8}$. The corresponding rate, for example, for the United Kingdom is 5.9 percent in 1960 and 10.8 in 2000. That Norway ranks low in terms of self-employment is also seen in more recent international comparisons, see the overview in Figure 9.

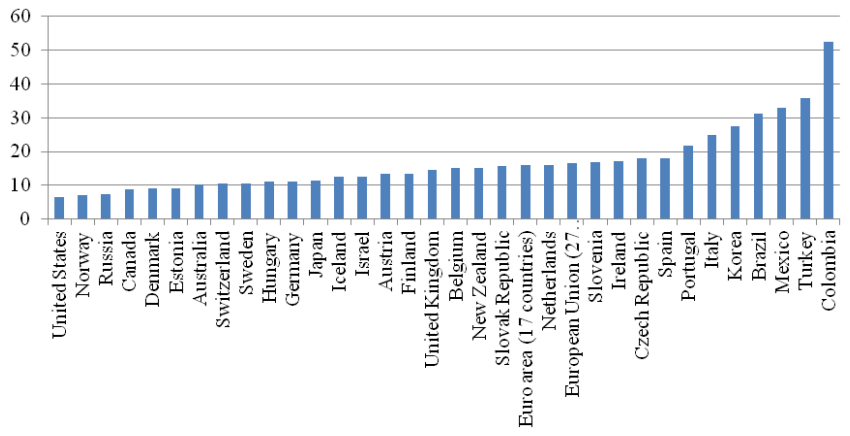

Source: OECD

Figure 9: Self-employment rates in OECD countries, 2013.

\subsection{Historical tax background}

As already noted, the 1992 tax reform enacted a dual income tax consisting of a combination of a low proportional tax rate on capital income and progressive tax rates on labor income. The system proliferated throughout the Nordic countries in the early 1990s, and the Norwegian version had a flat 28 percent tax rate levied on corporate income, capital and labor income, coupled with a social security contribution and a progressive surtax applicable to labor income. Double taxation of dividends was abolished, as taxpayers receiving dividends were given full credit for taxes paid at the corporate level, and the capital gain tax system exempted gains attributable to retained earnings taxed at the corporate level.

The separate schedules for capital and labor income created obvious incentives for taxpayers to recharacterize labor income as capital income. To limit such tax avoidance, the 1992 reform introduced the "split model" for the self-employed and closely held firms, defined as businesses in which more than two-thirds of the shares were owned by the active owner(s). Rules were established for dividing business income into capital and labor income, and the resulting imputed labor income was subject to a

8 Note that this reduction most likely is influenced by increased female participation rates over the period and that these newcomers in the labor market are less inclined to move into self-employment. 
social security contribution and a two-tier surtax. The top marginal tax rates for wage earners and owners of small businesses (the self-employed and owners of closely held firms) were $48.8^{9}$ and 51.7 percent in 1992. Between 1992 and 2004, both the threshold for the second tier of the surtax and tax rates increased, resulting in statutory tax rates for wage earners as shown for 2004 (the last year before the reform) in Figure 10, with 55.3 percent at the maximum.

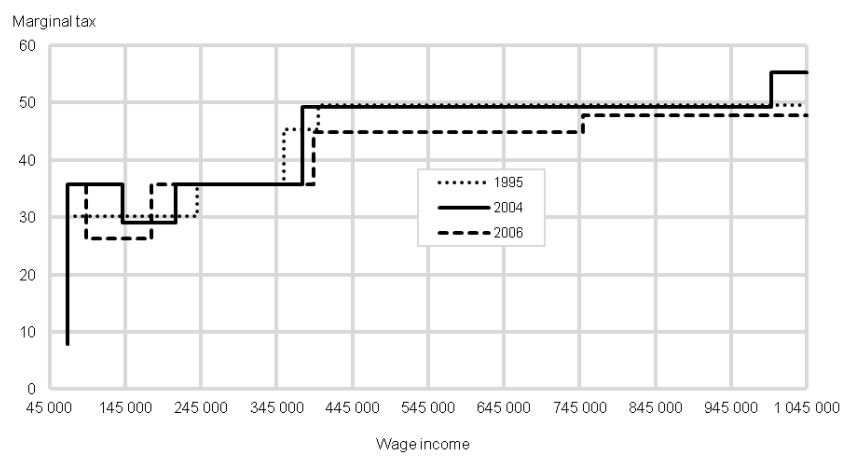

Figure 10: Marginal tax rates: 1995, 2004, and 2006.

Under the split model, an imputed return to the capital invested in the firm is calculated by multiplying the value of the capital assets by a fixed rate of return on capital (stipulated as the interest rate on government bonds, plus a risk premium). The imputed return to capital is taxed at the corporate rate, which equals the capital income tax rate at the individual level. Business profit net of imputed return to capital is the imputed return to labor, which is taxed as labor income, the so-called personal income, and independent of whether the income is retained in the firm or transferred to the owner.

The main idea was taxation of "labor income" should follow a similar schedule, independent of whether the income came from wage payments or was obtained by the split model. But a separation was introduced, for income above $34 \mathrm{G}^{10}$, the tax rate goes down to 28 percent, thus suggesting that income above that level comes from returns to capital. Moreover, the 1990s saw increasing pressure on the dual income tax system, resulting in numerous "patches." A distinction between liberal professions (lawyers, dentists, doctors, and other independent contractors delivering services to the public) and other professions was introduced in terms of ceilings where the labor

9 Excluding the employers' social security contribution. 10 The basic amount in the social security system, $G=36,500$ NOK in 1992. income part was taxed according to the capital income tax rate (28 percent). This is visible in the development in the schedule for the self-employed in nonliberal professions, as depicted in Figure 11, with marginal tax rates kept low at the 28 percent rate in intervals (see schedule for 2004). In some years, there was also a separate schedule for selfemployed in the liberal professions, but in 2004, the two "drops" down to 28 percent are reserved for the nonliberal professions.

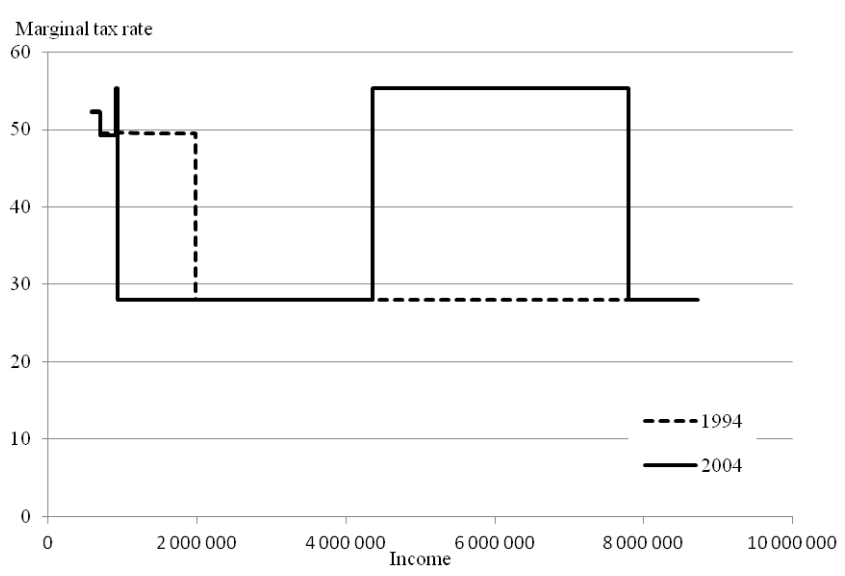

Figure 11: Development in marginal tax rates for personal income under the split model, nonliberal professions.

As already remarked, a main problem of the post1992 tax schedule was the built-in tension stemming from a rather large difference between marginal tax rates on dividends to shareholders and wage income for the selfemployed. This resulted in organizational shifts, as business owners chose to move out of the split model (selfemployed and closely held firms) and to be paid in term of tax-favored dividends from a fully incorporated firm (Thoresen and Alstadsæter (2010)). In data, we will observe this as shifts in the organizational form and shifts in the type of payment. Figures 12 and 13 provide indicative evidence of such tax-induced maneuverings, as we see a growth in the number of widely held firms in the period 1993-2013 (Figure 12) and also observe an increase in transfers of dividends in the period leading up to the tax reform in 2006 (Figure 13). With respect to the pattern of Figure 13, dividend payments dropped in 2001 because of a temporary tax on dividends and then rose steadily from 2002 and onwards, after the appointment of a government tax commission with the mandate to consider a new tax on dividends. The Norwegian tax reform of 2006, which was announced several years in advance, introduced incentives to step up dividends prior to the reform. It caused 
strong timing effects, as found by Alstadsæter and Fjærli (2009) and as shown in Figure $13^{11}$.

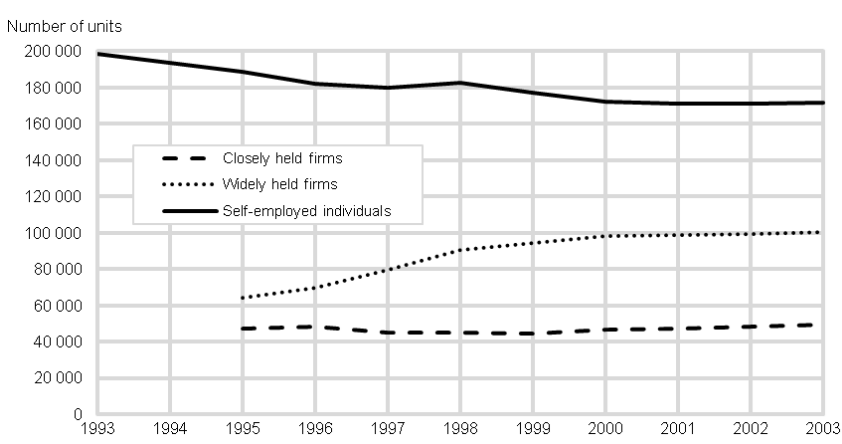

Source: Thoresen and Alstadsæter (2010)

Figure 12: Norwegian small businesses by organizational form, 1993-2003.

The reform of 2006 emerged as an attempt to create a system that would prevent taxpayers from transforming labor income into capital income to benefit from the lower flat rate applied to the latter. See Sørensen (2005) for the wider background to the reform and steps taken to adjust the dual income tax. The split model is superseded by rules of a more general nature, and dividends (and capital gains stemming from shares) are taxed at both the corporate and individual levels. The current dividend tax is levied on individual dividend incomes and capital gains above a rateof-return allowance, that is, on profits above a risk-free rate of return, by 48.2 percent at the maximum in $2006^{12}$. Moreover, top marginal tax rates on wage income were cut to narrow the differences between the marginal tax rates on capital income and labor income, see Figure 10.

Recent demand for revisions of the Norwegian tax schedule, resulting in the report from the so-called Scheel commission (NOU, 2014: 13), mainly comes from developments along another tax dimension: the closer integration of markets as a result of globalization has motivated various countries to amend their corporate taxation, that is, we have witnessed a widespread decrease in corporate tax rates. While a corporate tax rate at 28 percent was rel-

11 Similar pattern are also described for Finland by Kari (Karikallio) for Finland.

12 The figure for the marginal tax rate on dividends in 2006 is derived as follows. Capital income is taxed at a 28 percent rate at the corporate level, and the remaining 72 percent is transferred to the individual and taxed at 28 percent (above the rate of return allowance), resulting in a combined rate of 20.16 percent $(0.72 \times 0.28)$, which is then added to the corporate level rate. Now, in 2015, the corporate tax rate is reduced to 27 , which alters the calculation correspondingly.

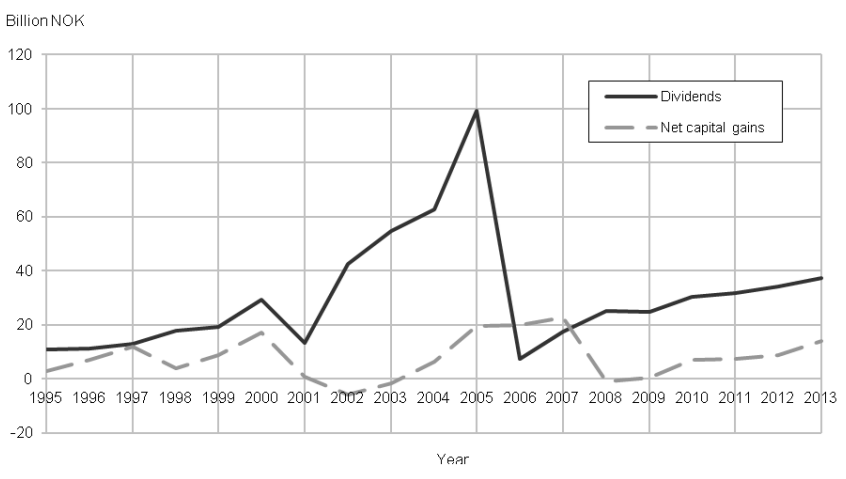

Figure 13: Dividends and net capital gains 1995-2013.

atively low in 1992, currently, there are many countries around Norway, for example, all the other Nordic countries, with lower rates (NOU, 2014: 13, p. 17). Figure 14 shows that Norway is at the high end of the corporate tax level ranking in 2014. The corporate tax rate was reduced to 27 percent in that year.

\subsection{Tax treatment of wage earners and the self-employed}

As already described, individuals in Norway pay income taxes calculated with respect to two tax bases. The first base is the so-called "ordinary income." It includes all gross taxable income accruing to the individual (e.g., wages, pensions, business income, income from shares, and other taxable capital incomes) minus the basic allowance, various deductible losses and expenses, and other allowances. A flat rate is levied on the ordinary income after the deduction of the applicable allowances.

The second base is called the "personal income" and is defined as the sum of all gross labor incomes, pension income, and business income above the rate of return allowance. No other allowances are considered in this calculation. The social security contribution for both employees

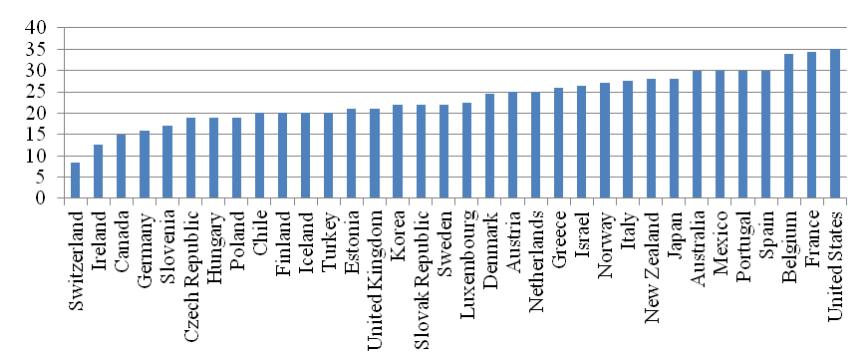

Source: OECD

Figure 14: Corporate tax rates in OECD countries (2014). 
and self-employed and the two-tier surtax are paid according to this second base.

Figure 15 presents the marginal tax rate on wage income for a person taxed in tax class 1 with only standard deductions in 2015. No taxes on income are paid until the lower limit for paying national insurance contribution is reached ${ }^{13}$. The social security contribution has to be paid at a leveling rate of 25 percent until it becomes equivalent to pay the general rate, 8.2 percent on total wage income. If total income is larger than the sum of the personal allowance (personfradrag) and the basic allowance (minstefradrag), tax on ordinary income will be paid ${ }^{14}$. In the example, the tax payer pays 27 percent tax on income exceeding $89,050 \mathrm{NOK}$, facing a marginal rate of 23.6 percent $(8.2 \%+27 \%(1-0.43))$. When the maximum basic allowance is reached $(89050 / 0.43=207093)$, the marginal tax rate increases to 35.2 percent $(8.2 \%+27 \%)$. Finally, on gross incomes exceeding 550,550 NOK, a surtax of 9 percent is levied, which increases to 12 percent for gross income larger than 885,600 NOK (second tier).

As the self-employed individuals invest both capital and labor in their businesses, part of the profit generated by the business is capital income and some of it comes from return to labor. After the revision of the dual income tax in 2006, the owners of sole proprietorships are

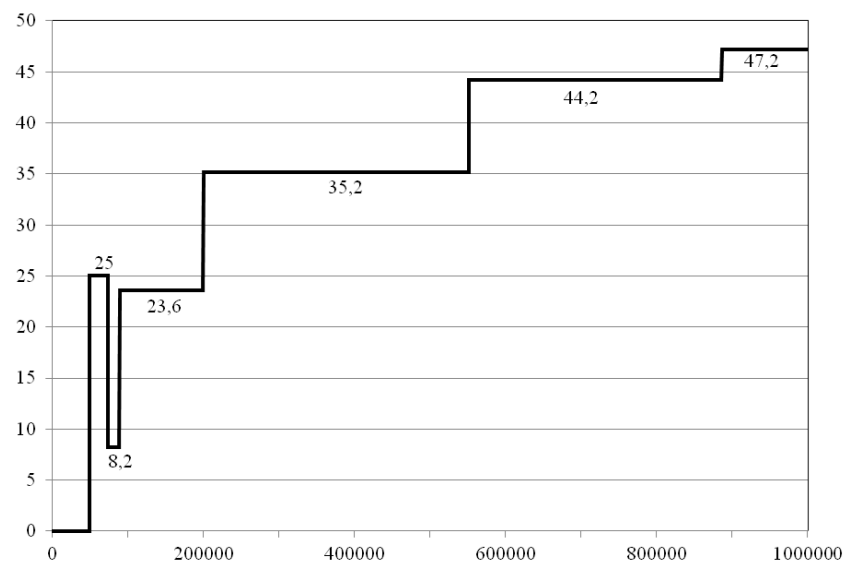

Figure 15: Marginal tax rate on wage income, 2015.

13 This threshold was 39,600 NOK from 2008 to 2014. For the year 2015, it has been increased to 49,650 NOK.

14 The personal allowance is a general basic deduction from the ordinary income, that is, it applies to all income (wages, pensions, capital, and entrepreneurial income). In 2015, it is 50,400 NOK for a class 1 taxpayer. The basic allowance applies for wage income and pensions, as a proportion of income with upper and lower limits. In 2015, the rate for wage incomes was 43 percent and the lower and upper limits were 4,000 and 89,050 NOK.
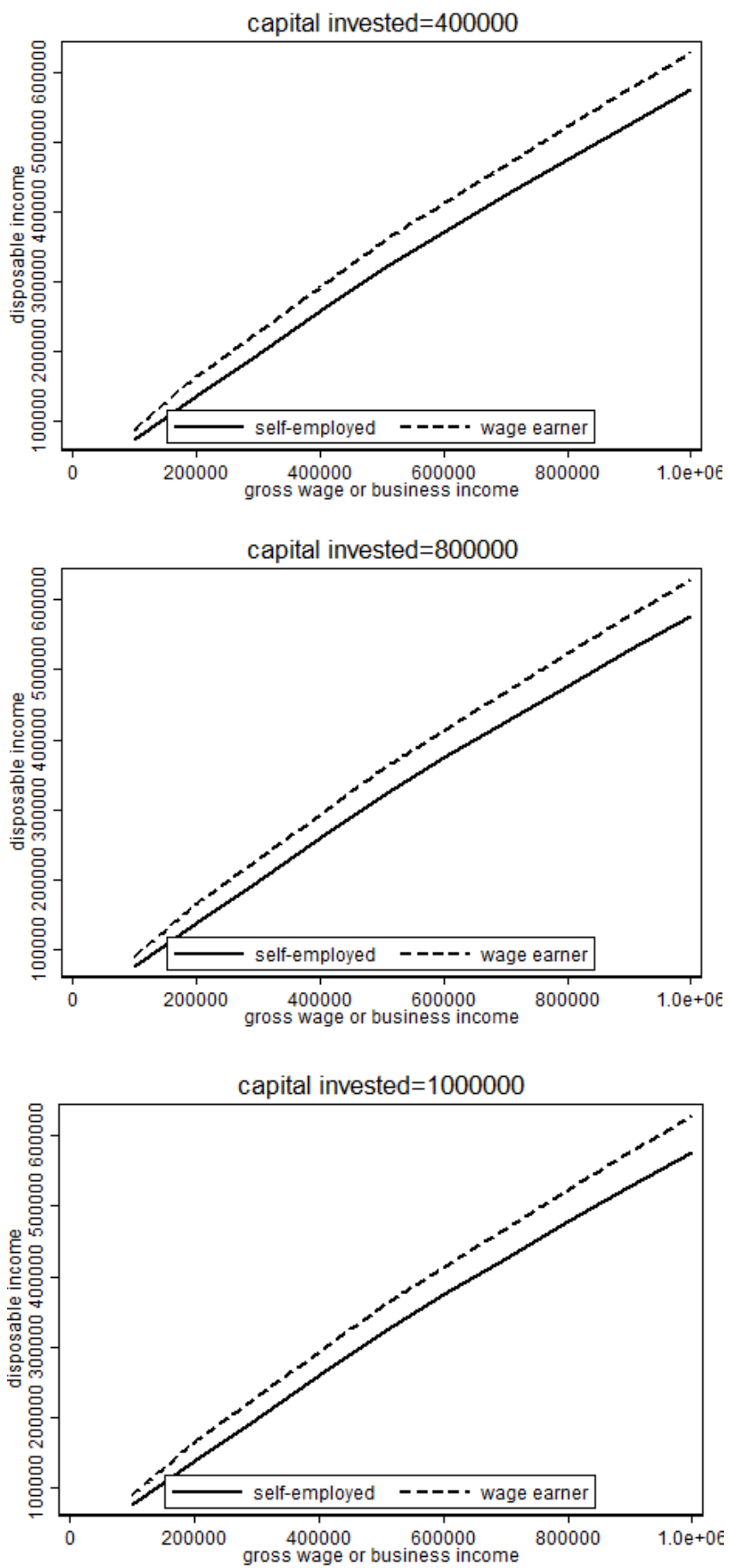

Figure 16: Disposable income for wages and business incomes, various levels of invested capital.

taxed under the self-employed model (foretaksmodellen). According to the new rules, business income from a sole proprietorship activity in excess of the risk-free return allowance, calculated on the invested capital, is taxed as imputed personal income and is subject to surtax and so- 
Table 6: Some key figures on taxation of wage earners and self-employed, 2010-2015.

\begin{tabular}{ccccccccc}
\hline Year & $\begin{array}{c}\text { Tax rate on } \\
\text { ordinary } \\
\text { income }\end{array}$ & $\begin{array}{c}\text { Social } \\
\text { security } \\
\text { rate (wage) }\end{array}$ & $\begin{array}{c}\text { Self- } \\
\text { employed } \\
\text { social } \\
\text { security } \\
\text { rate }\end{array}$ & $\begin{array}{c}\text { Personal } \\
\text { allowance } \\
\text { (NOK) }\end{array}$ & $\begin{array}{c}\text { Basic } \\
\text { allowance, } \\
\text { rate }\end{array}$ & $\begin{array}{c}\text { Self- } \\
\text { employed } \\
\text { safe rate of } \\
\text { return }\end{array}$ & $\begin{array}{c}\text { First } \\
\text { surtax } \\
\text { rate }\end{array}$ & $\begin{array}{c}\text { Second } \\
\text { surtax } \\
\text { rate }\end{array}$ \\
\hline 2010 & 28 & 7.80 & 11 & 41,210 & 36 & 2.20 & 9 \\
2011 & 28 & 7.80 & 11 & 43,600 & 36 & 2.10 & 9 \\
2012 & 28 & 7.80 & 11 & 45,350 & 38 & 1.60 & 9 \\
2013 & 28 & 7.80 & 11 & 47,150 & 40 & 1.50 & 9 \\
2014 & 27 & 8.20 & 11.4 & 48,800 & 43 & 1.20 & 9 \\
2015 & 27 & 8.20 & 11.4 & 50,400 & 43 & & 12 \\
\hline
\end{tabular}

cial security contribution ${ }^{15}$. This is in contrast to the taxation of partners in partnerships (deltakermodellen) and shareholders (aksjonærmodellen). A partner in a partnership pays taxes according to his share of the partnership's profits on an annual basis, while corporations are subject to a company tax. In addition, taxation arises when the individual partner or shareholder receives returns (dividends) or capital gains on the investment above a risk-free rate of return.

Social security contributions for self-employed individuals are higher than the rate for wage earners, to (partly) compensate for self-employment income not entering into the tax base for the payroll tax, see Figure 17 on the latter schedule.

Table 6 summarizes the principle features of taxation of wage and business income for individuals in class 1 , not belonging to the primary sector or living in Nord-Troms and Finnmark, for the period 2010-2015.

To visualize possible tax incentives for choosing selfemployment over paid employment, Figure 16 compares disposable incomes for wage earners and self-employed under the 2013 tax rules. Different amounts of capital invested are also considered in the three graphs. For simplicity, it is assumed that the self-employed taxpayer has no extra deductions, including no depreciation of the capital investment.

The graphs show that disposable income for wage earners is higher for all the ranges of gross income and capital invested considered. This is mainly they pay higher social security contribution, to partly offset the lack of contribution share paid by employers for the employees. Fig-

15 The basis for calculation of risk-free rate is the arithmetic average observed on the treasury bills with three months maturity, as published by Norges Bank every year. In 2014, it was 1.24 percent.

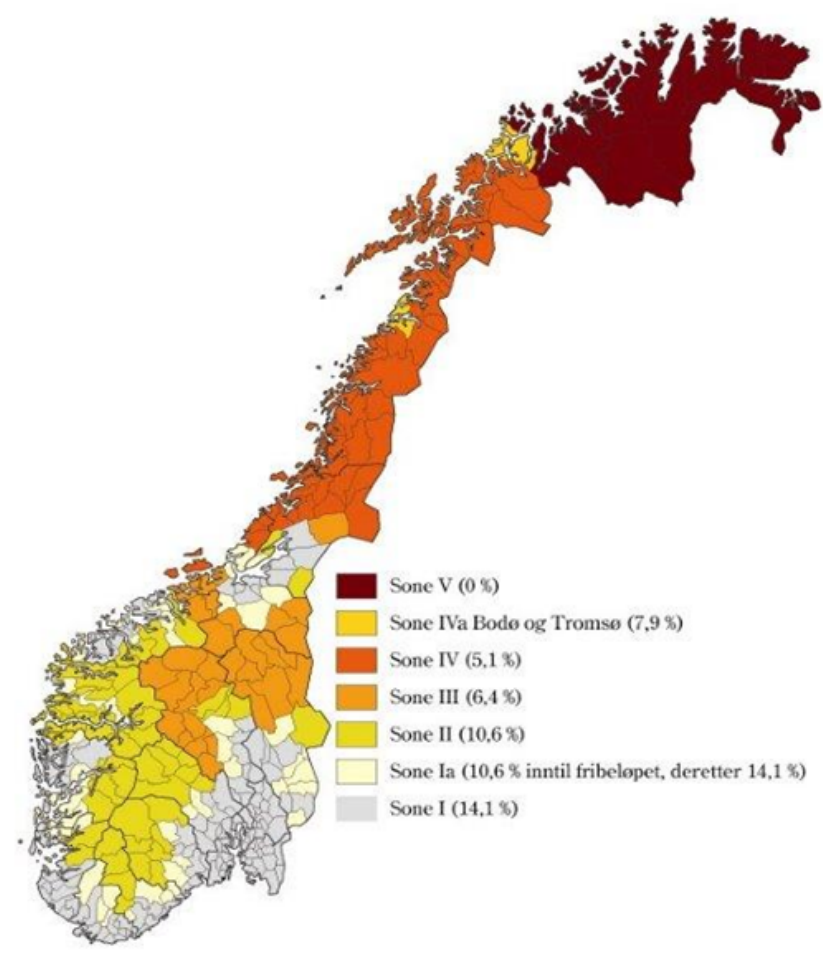

Figure 17: Employer social security contribution in Norway.

ure 17 shows the payroll taxation schedule, and it illustrates that there is substantial regional variation in the employer payroll taxation, ranging from 0 in the northern counties to 14.1 percent in the so-called Zone I (which includes the Oslo-area).

In a comparison of wage earners and self-employed, it is also important to point out that self-employed individuals receive lower social security benefits compared to the wage earners. For instance, in general, the self-employed individuals are not entitled to receive unemployment benefits and also the sickness benefits scheme gives lower cov- 
erage for self-employed persons, relative to the wage earners $^{16}$. These differences in the social security coverage can also be important determinants of whether to choose selfemployment over wage employment (or dividends over wage payment for an active shareholder). Fjærli and Lund (2001) showed theoretically and found empirical indications of taxation not being the only motivation behind the choice of monetary compensation for the owners of corporations (wage or dividends) and also that the right to receive social benefits is important in shaping decisions.

It is generally believed that activities of the selfemployed are sensitive to taxes and tax changes. However, there is a whole range of issues that come into the decision-making, such as valuation of "being one's own boss" and attitudes toward risk ${ }^{17}$. Moreover, there may exist tax incentives for a potential employer to encourage a candidate employee to provide his/her labor organized in the form of self-employment, to avoid both the protections (long-term labor contracts) and costs (employers' social security contribution) connected with a dependent employment relation. There are indeed strict criteria set up by the tax authority that distinguish sole proprietorships and regular employees. However, recent but circumscribed evidence describe the so called "bogus self-employment" phenomenon. Friberg (2011) suggested that while the Norwegian workers in the building sector to a large extent are permanently employed, the Polish labor migrants in the same sector are characterized by a high share of selfemployment.

\subsection{Taxation of sole proprietors, partnerships, and incorporated firms after 2006}

Results of the optimal tax literature leave one with no strong case for taxing capital income (Boadway (2005)). Dual income taxation (with a flat tax rate on capital income and progressive rates on gross labor and pension income) avoids or eases some of the problems of the comprehensive income tax. For example, a lower rate on capital reduces the discrimination against "early earners" and "late spenders" in a life-cycle perspective and is likely prefer-

16 The right to sickness benefit only applies from the $17^{\text {th }}$ day of sickness, as the benefit from the first to the $16^{\text {th }}$ day is covered by employers for the employees. Furthermore, the self-employed only receive sickness benefits at $65 \%$ of their income basis, whereas wage earners are fully insured (the self-employed have, however, the possibility to opt for full sickness benefits, subject to a fee).

17 See the overview in Parker (2004). able for investments in innovations and risky projects. However, it usually introduces a trade-off between advantageous capital income taxation and avoiding tax motivated income shifting from the labor to the capital income. As already seen, the 1992 tax reform, and in particular the adjustments of the schedule in the 1990s, generated tax-motivated income/organizational shifts. In particular, shifts toward organizational forms that were not subject to the split model have been documented, see Thoresen and Alstadsæter (2010).

Until 2006, the tax treatment of active shareholders in closely held corporations and partners in a partnership under the Norwegian tax system was similar to that of the self-employed. Income splitting was mandatory for partnerships and corporations with active owners. The 2006reform abolished the split model for partners in a partnership and active shareholders in corporations and instead introduced the shareholder model (aksjonærmodellen) and the partnership model (deltakermodellen) ${ }^{18}$.

There are three types of partnerships in Norway, depending on the liability of the partners. In the limited partnership (kommandittselskap, KS), some of the partners will be general partners (unlimited liability) and others are limited partners (obligations are limited to each partner's share of the total committed capital). When organized as general partnerships, instead, the partners can choose to be jointly liable for all debts of the partnership (ANS) or to be responsible for a percentage agreed upon (DA).

The 2006 tax reform introduced a variant of the shareholder model for the distribution of partnership profits for individual partners. In contrast to the taxation of selfemployed, the full taxation of the return to the firm's labor and capital is only attained when profits are distributed to the partners. In particular, there is shielding of a normal rate of return for partnerships, which implies that only the profit in the hand of the partners exceeding a risk-free return to the capital invested in the partnership is taxed at the maximum rate. The maximum marginal tax rate of the effective tax rate on withdrawals from a business income is 46.7 percent $(27 \%+27 \%(1-0.27))$ in 2015 . If a partner receives payments for work in the firm, this is taxed as business income.

As the 2006-reform introduced the so-called shareholder model for taxation of personal shareholders, the distinction between active and passive shareholders was abolished. Furthermore and most importantly, the new

18 Partnerships are companies consisting of two or more partners that are jointly or fully responsible for the financial liabilities of the firm. 
model reintroduced the double taxation of dividends and capital gains, at the corporate and the individual level, to reduce the tax treatment differences in the taxation of earned income and returns to capital. However, all shareholders would be allowed a tax exempt amount equal to a risk-free interest on their tax base cost of each share. If the shareholder opts to refrain from dividends, the unused tax-free amount multiplied by the risk-free rate of return will be carried forward. This is an important feature to ensure neutrality of the taxation of dividends and gains.

The corporate tax system has maintained its focus on neutrality, inspired by the main reasoning behind the 1992 reform. The main difference between the tax treatment of companies and partnerships is due to profits of partnerships being taxed in the hands of the partners, whereas the profits of the limited companies are taxed inside the firm, but the same tax rate applies (27 percent since 2014). Moreover, when distributed, taxation of profits/dividends or capital gains is rather close. Personal shareholders and partners are taxed at a 27-percent rate on the part that is not tax exempted. The taxation models for these two different organizational forms are basically the same; a main difference is that work remuneration for a partner is taxed as business income, while work remuneration of an active shareholder is taxed as wage.

The adjustments to the dual income taxation have in general reduced the difference between the top marginal tax rate on labor income and capital income, and therefore, most likely reduced the incentives to convert labor income to capital income. Figure 18 shows the difference between the top marginal tax on wages (including the highest rate for the employers' social security contribution) and dividends (including the corporate tax) for some years prior to and after the 2006 reform. The top marginal tax on wages is 53.7 percent $[(8.2+27+12+14.1) /(100+14.1)]$, whereas dividends are taxed by 46.7 percent on the margin in 2015.

The present tax system includes an additional distinction between the taxation of personal and corporate shareholders. Corporate shareholders are exempted to pay tax on dividends received and capital gains on shares. The purpose of introducing the so-called exemption method (fritaksmetoden) is to avoid chain taxation of transfers within the corporate sector (Ministry of Finance (2011)). The exemption method and the shareholder model together are meant to assure that income proceedings from corporate activities are taxed once at the firm level and once in the hand of the personal shareholder.

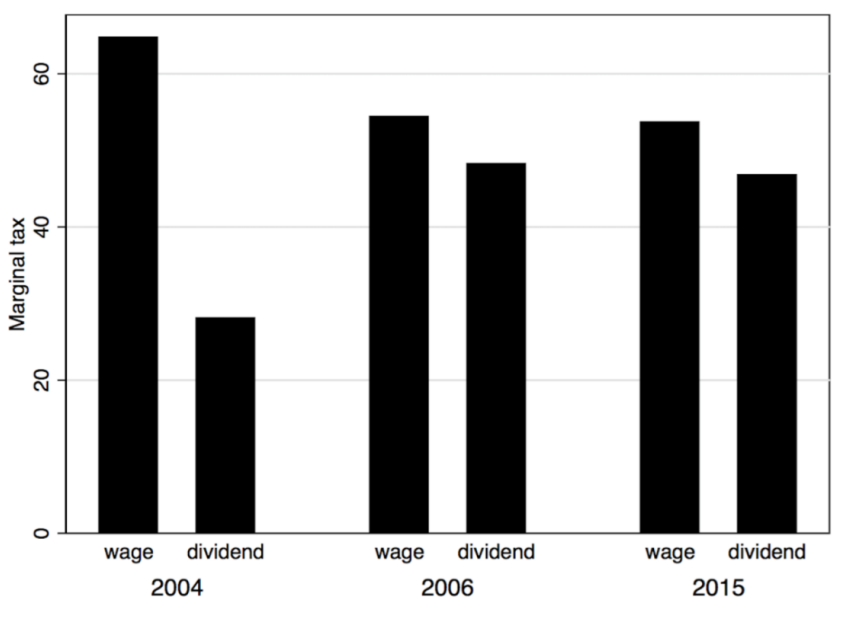

Figure 18: Top marginal taxation of wages and dividends.

\subsection{Financing and entrepreneurial activities}

An important part of the philosophy underlying the dual income tax is that the capital income tax base should be broad, to ensure the greatest possible degree of tax neutrality. Sørensen (2005) argued that the shareholder income tax is equivalent to a neutral cash flow tax, that is, neutral with respect to investment and financing decisions. However, Lindhe and Södersten (2012) suggested that the shareholder tax represents an incentive for the shareholder to hold on to his/her investment in corporate equity compared to investing outside the stock market, when the pre-tax rate of return on shares is determined on international markets (a lock-in effect).

The substantial increase in dividends after the 2006 tax reform, as seen in Figure 13, did not necessarily reduce the size of a firm, as discussed by Alstadsæter (Kopczuk). For personally owned firms (closely held), much of the capital was reinjected into the firms. Further, Fjærli and Raknerud (2014) discussed (theoretically and empirically) to what extent the new shareholder tax and the wealth tax harm investments and thereby the growth of firms. It is found that firms are not affected when investments are financed by retained earnings, taxed at the margin, which is typical for a mature firm ${ }^{19}$.

The main tool to encourage entrepreneurial activities through the tax system in Norway is the so-called SkatteFUNN scheme. It came as a response to observing that research and development (R\&D) spending of the Norwe-

19 It is also worth noting that Keuschnigg and Dietz (2007) found advantageous growth effects for Switzerland, when introducing a dual income tax in combination with an allowance for corporate equity (ACE). 
gian business sector as a share of gross domestic product (GDP) is below the OECD average. To stimulate private R\&D investment, the Norwegian government has traditionally used direct R\&D subsidies. In 2002, this policy was supplemented with an R\&D tax credit scheme-SkatteFUNNfor small and medium-sized enterprises (SMEs), which by 2003 became available to all firms. SkatteFUNN provides a volume-based tax credit to firms with an R\&D project that the Research Council of Norway (RCN) has approved. A tax credit of 18 percent (20 percent for SMEs) of R\&D costs for the approved project is deductible from the firm's income tax, with a project cost cap roughly equal to half a million Euros. If the firm does not pay any tax or pays less tax than the tax credit, the credit is paid to the firm as if it were a grant. In an evaluation of the scheme, see Cappelen et al. (2012), it is found that the SkatteFUNN scheme stimulates innovations in the form of new products for the firm and new production processes but not major product innovations $^{20}$.

\subsection{Do the self-employed shift back?}

As already discussed, and as indicated by Figure 12, the tax schedule prior to the 2006 reform generated organizational shifts. Thoresen and Alstadsæter (2010) retrieved such effects in micro data, when combining information about firms and owners and the link between them, the latter obtained from the Register of Shareholders. The behavior of more than 167,000 owners of small businesses, initially organized as self-employed or as a closely held corporation (defined as businesses in which more than twothirds of the shares were owned by the active owner) was followed. A time window is assigned for the business owners to shift organizational form, and characteristics of the "shifters" are discussed in relations to the characteristics of those decided to remain in the chosen organizational form. It was found that (1) a high imputed labor income under the split model and (2) belonging to a human-capitalintensive firm increase the probability of moving into a widely held corporation. Moreover, taxpayers who shifted organizational form experienced a substantial increase in posttax income, compared to the "stayers." IV regressions suggest that organizational shifts increase income growth by as much as 40 percentage points ${ }^{21}$. This suggests that

20 See also Fjærli (Iancu) on information on entrepreneurship in Norway.

21 The OLS results suggest smaller effects: around 9 percentage points increase in income. for a particular group of business owners able to adapt to features of the particular dual income tax system that was in place prior to 2006, the income gains have been large. Such findings certainly raised issues concerning the legitimacy of this type of tax schedule and suggested that the politicians had good reason to alter the schedule, reducing the difference between marginal tax rates of wage income and dividends.

Given the pattern reported in Figure 12, it is interesting to see how the different organizational forms develop after the tax reform of 2006. In Figure 19, we put together some trends in different types of firms for the time period from 2004 to 2013. The categorization of firms is different from the classifications in Figure 12, as another data source is now used, based on the so-called Central Register of Establishments and Enterprises (CRE), administered by Statistics Norway (Statistics Norway (2014b)) ${ }^{22}$. We have also used data from the Income and Wealth Statistics for Households (Statistics Norway (2014a)), to establish the time series in Figure 19 referred to as "Self-employed." By the latter data source, we have calculated the number of self-employed from repeated cross sections, based on a definition of self-employment derived from reporting higher business income that wage income.

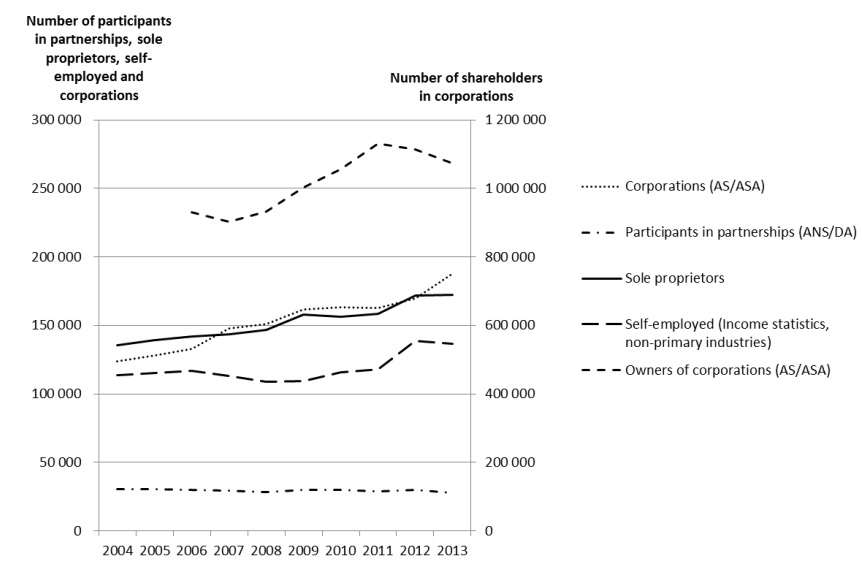

Figure 19: Number of owners and number of firms by organizational form, 2004-2013

Even though Figure 19 only presents "indicative evidence" of effects of the 2006 tax reform, we do not see the same pattern in the number of self-employed as seen in Figure 12 (attributed to effects of the dual income

22 The Central Coordination Register for Legal Entities (the so-called Brønnøysund-register) and the Register of Shareholders are key data sources. 
tax schedule in place prior to 2006). The time series for the self-employed show increase in the number of selfemployed after 2006. Moreover, the number of partnerships appears to be rather stable (around 30,000 individuals involved) over the time period.

\subsection{Concluding remarks}

The taxation of the self-employed, partnerships, and other business forms continues to be on the policy agenda in Norway, as illustrated by the recent report from the Scheel commission (NOU, 2014: 13). This report has described the main features of the taxation of the self-employed and partnerships and their relation to the taxation of wage earners and other business forms.

We now see some indications of the number of self-employed increasing, after observing a (likely) taxinduced reduction under the dual income tax prior to the 2006 tax reform. However, more research is needed in order to understand to what extent recent changes in the tax system have influenced the role of self-employment in the Norwegian economy.

\section{Bibliography}

Alstadsæter, A. and E. Fjærli (2009). Neutral Taxation of Shareholder Income? Corporate Responses to an Announced Dividend Tax. International Tax and Public Finance, 16, 571-604.

Alstadsæter, A., W. Kopczuk and K.Telle (2014). "Are Firms Tax Shelters?”. In J. Brown (ed.) Tax Policy and the Economy, 28, 1-32.

Berglann, H., E.R. Moen, K. Røed and J.F. Skogstrøm (2011). Entrepreneurship: Origins and Returns. Labour Economics, 18, 180193.

Boadway, R. (2005). Income Tax Reform for a Globalized World: The Case for a Dual Income Tax. Journal of Asian Economics, 16, 910927.

Cappelen, A., A. Raknerud and M. Rybalka (2012). The Effects of R\&D Tax Credits on Patenting and Innovations. Research Policy, 41, 334-345.

Fjærli E., D. Iancu and A. Raknerud (2013). Facts about Entrepreneurship in Norway. Who Become Entrepreneurs and How Do They Perform. Reports 52/2013, Statistics Norway.

Fjærli E. and D. Lund (2001). The Choice between Owner's Wages and Dividends under the Dual Income Tax. Finnish Economic Papers, 14, 104-119.

Fjærli, E. and A. Raknerud (2014). The Effect of Business Taxes on the Growth of Entrepreneurial firms. Manuscript prepared for the OFSseminar "Taxing capital income: the role of business and personal taxation”, University of Oslo, 4-5 April, 2014.

Friberg, J.H. (2011). Culture at Work: Polish Migrants in the Ethnic Division of Labour on Norwegian Construction Sites. Ethnic and Racial Studies, 35, 1914-1933.
Kari, S., H. Karikallio and J. Pirttilä (2009). The Impact of Dividend Taxation on Dividends and Investment: New Evidence Based on a Natural Experiment. CESifo Working Paper No. 2756, Munich, Germany.

Keuschnigg, C. and M. Dietz (2007). A Growth Oriented Dual Income Tax. International Tax and Public Finance 14, 191-221.

Lindhe, T. and J. Södersten (2012). The Norwegian Shareholder Tax Reconsidered. International Tax and Public Finance, 19, 424-441

Ministry of Finance (2011). Evaluation of the 2006 Tax Reform. Report No. 11 to Stortinget.

NOU (2014: 13). Kapitalbeskatning $i$ en internasjonal $ø$ konomi (Capital Taxation in an International Economy. https://www.regjeringen.no/en/dokumenter/nou-201413/id2342691

OECD (2014). http://data.oecd.org/emp/self-employment-rate.htm Parker, S.C. (2004). The Economics of Self-Employment and Entrepreneurship. Cambridge University Press, Cambridge.

Raknerud, A. and M. van Praag (2014). The Entrepreneurial Earnings Puzzle. Evidence from Matched Person-Firm Data. Discussion Papers 789 , Statistics Norway.

Stambøl, L. (2010). Klarer selvstendig næringsdrivende å opprettholde sin virksomhet over tid? Økonomiske analyser 2/2010. Statistics Norway.

Statistics Norway (2014a). http://www.ssb.no/en/inntekt-ogforbruk/statistikker/ifhus/aar/2014-12-17?fane=om\#content.

Statistics Norway (2014b). http://www.ssb.no/en/virksomheterforetak-og-regnskap/statistikker/eigarskap.

Sørensen, P.B. (2005). Neutral Taxation and Shareholder Income. International Tax and Public Finance, 12, 777-801.

Thoresen, T.O. and A. Alstadsæter (2010). Shifts in Organizational Form under a Dual Income Tax System. FinanzArchiv/Public Finance Analysis, 384-418.

\section{Sweden}

\section{By Paul Christian Elger and Andreas Högberg ${ }^{\star}$}

When economists evaluate the efficiency of a tax system, they consider the cost of raising tax revenue in terms of the behavioral response that the tax imposes. An example of such a behavioral response is when a different legal form is chosen for a firm than what would have been the

Paul Christian Elger: Ph.D., Ministry of Finance, Division for Tax Policy Analysis, Sweden; Email: palleelger@gmail.com

Andreas Högberg: Ph.D., Minstry of Finance,Sweden; Email: andreas.hogberg@regeringskansliet.se

* The authors have benefited tremendously from comments and help provided by Nina Öhrn Karlsson, Bo Stoltz, Marianne Kilnes, Lars Lindvall, and Martin Kjellqvist. All remaining errors are ours. The views expressed in this report is solely those of the authors and should not be interpreted as reflecting the views of the Ministry of Finance. 
founders' choice in the absence of taxes. Such changes in behavior represent efficiency losses. If different legal entities favor different types of investments, tax differences across type of entity can potentially affect which projects that are carried out. Moreover, tax-induced changes in firms' legal type is likely to cause a loss of tax revenue for the legislator. Hence, tax differences between different legal entities matter for both the legislator and the founders of firms. The Swedish taxation of different legal entities aims at being neutral between different types of firms. However, in practice, a neutral system is difficult to achieve, and the Swedish tax treatment varies to some degree depending on organizational form. In this article, we discuss these differences in detail. Naturally, these differences in tax treatment imply that the return to an investment also differs depending on which legal entity it is carried out in. This will in turn affect the different entities' access to funding. Access to finance is not further discussed in this paper.

Tax rules may also affect how income is distributed across tax bases, tax brackets, and over time, the so-called income shifting. Wage earners have their wages reported by a third party, that is, their employer. Hence, they cannot affect how their incomes are reported. Self-employed and managing owners, on the other hand, can to a much larger extent affect how their income is reported. An inherent challenge facing the legislator in a dual income tax system and a large difference in the marginal tax rate on capital income as compared to labor income is to prevent income shifting between the two tax bases. In order to prevent such shifting, legislators in these countries have implemented different versions of an income splitting system for owners of closely held corporations.

From a policy perspective, a variety of nontax regulations will of course affect why a firm chooses a particular organizational form or why the firm's management chooses to distribute a certain level of dividends. In the following text, we focus strictly on the role of tax incentives. The structure is as follows. First, we focus on how firms are taxed depending on organizational form. Second, we discuss how the taxation of different organizational forms and the labor income tax system in turn affects the incentives of someone that can channel income through a company instead of as employed. The third section discusses recent policy changes and current initiatives. Finally, the fourth section gives some concluding remarks.

\subsection{Differences in Corporate Taxation Depending on Legal Entity}

One aim of the rules for taxation of companies is to achieve neutrality between different types of legal entities. Owners of corporate entities are taxed on income distributed as wage income in the same way as other wage earners, while income distributed as dividends or capital gains are taxed both at the corporate level and as capital income at the individual level. Owners of noncorporate firms are taxed only at the individual level and may distribute income as either wage or capital income.

\subsubsection{Background}

The trend in number of Swedish firms is increasing for all types of legal forms except for unlimited partnerships (handelsbolag), which have had a slightly decreasing trend since 2004. In 2010, the required capital to start a limited liability company (aktiebolag) was decreased from 100000 to 50000 SEK, which resulted in an increase in the number of limited liability firms. Interestingly, during the same period, the number of sole proprietorships (enskild näringsidkare) also increased at a higher pace than usual. The composition of firms with different types of legal form tends to be stable over time.

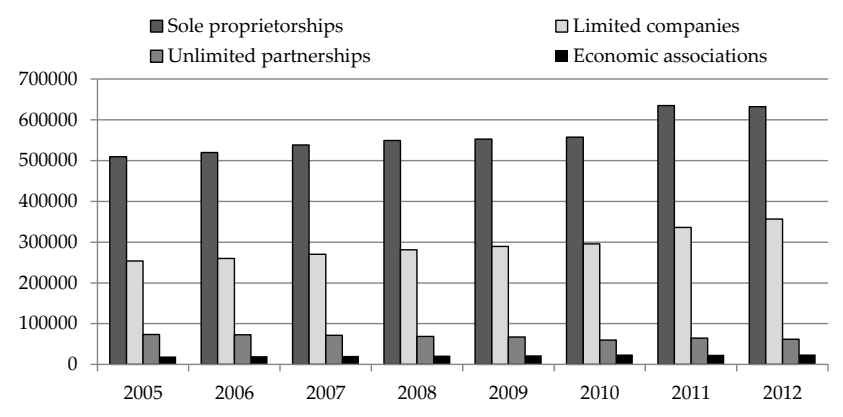

Source: Swedish Tax Agency (2014)

Figure 20: Number of firms per legal form 2005 to 2012.

The sole proprietorships are generally small in size but more numerous than the limited liability companies. In 2012, sole proprietorships made up about 60 percent of the total number of companies, but their share of total turnover was less than 2 percent. The share of limited liability companies in total turnover in 2012 was 88.6 percent (Tax statistical yearbook of Sweden 2014). 
Table 7: Business income and final tax depending on legal entity 2012.

\begin{tabular}{|c|c|c|c|c|c|}
\hline & \multicolumn{3}{|c|}{ Limited Liability Companies } & \multirow[b]{2}{*}{$\begin{array}{l}\text { Economic } \\
\text { associations }\end{array}$} & \multirow[b]{2}{*}{$\begin{array}{c}\text { Sole } \\
\text { proprietorships/unlimited } \\
\text { partnerships }\end{array}$} \\
\hline & All & $\begin{array}{c}\text { Privately } \\
\text { Owned }\end{array}$ & $\mathrm{CHC}$ & & \\
\hline Business income & 330.7 & 298.2 & 75.7 & 0.8 & 6.1 \\
\hline Final tax & 120.6 & 111.6 & 26.7 & 0.5 & * \\
\hline
\end{tabular}

${ }^{*}$ These are mainly taxed on an individual level; hence, comparable data cannot be constructed.

Table 7 provides detailed descriptives on the business income and final tax burden depending on legal entity in 2012. Almost all business income originates from limited liability firms. Column 1 shows the business income and final tax for all limited liability companies. Column 2 excludes the publicly owned limited liability companies. Column 3 presents the subset that is closely held. From column 4, we see that economic associations only generate a marginal share of the total business income. As they are that small, we exclude them from the remainder of the analysis. For sole proprietorships, the individual is taxed for business income; hence, constructing comparable data is not feasible.

Corporate income tax revenues are severely skewed over time toward a few very large firms, whereas a multitude of small or very small firms contribute substantially less to the tax revenues. According to the tax statistics, around 0.01 percent of all limited liability firms paid 100 million SEK or more in corporate income tax in 2012, which corresponds to approximately 25 percent of the total corporate income taxes paid. On the other hand, 85 percent of the corporations paid 100000 SEK or less in corporate income tax in 2012. These firms contributed to about 6.5 percent of the total corporate income taxes paid in 2012. However, it should be noted that the numbers for 2012 are not representative for the level of corporate income tax revenues in a longer time perspective. Owing to the decrease in the corporate income tax rate from 26.3 to 22 percent in January 1, 2013, the 2012 taxation year may be considered as an anomaly in terms of corporate tax revenues. Firms, it seems, have chosen to increase their allocation of profits to the so-called "profit periodization reserve" (periodiseringsfond). This will postpone the taxation of their corporate income for 2012 until later, when the lowered corporate income tax rate will have effect.

\subsubsection{Differences in Taxation across Legal Entities}

As a separate legal entity, Swedish corporate firms first pay corporate income tax at 22 percent of its income. If the remaining profit is distributed as dividends to the owners, these are taxed as capital income. Depending on the nature of the firm, that is, if it is publicly traded or privately widely held, dividends are taxed at 30 or 25 percent. In spite of this tax difference, the observed Swedish delistings appear mainly motivated by other reasons. If the private corporation is closely held (fämansföretag), dividends are taxed at 20 percent up to a limit and taxed as wage income above that limit. The limit is connected to either the individual's invested capital or the size of the wage sum paid to all employees. Any dividend above this limitation (and below approximately 5 million SEK) is considered as return on labor instead of capital and, therefore, taxed as wage income. No social security fee is placed on dividends regarded as wage income. However, the dividends remain non-; hence, corporate income tax is also paid. Somewhat simplified, there are theoretical tax incentives for a minority shareholder of a privately held corporation to prefer to not be employed and thereby classified as passive owners (rather than employed whereby they are classified as active owners). As a minority shareholder, the influence over dividend payouts is expected to be limited. If the minority shareholder is active, he may, therefore, face an uncertainty of paying capital income tax at 20 percent of the dividend, or up to 57 percent as wage income tax. The passive owner face no such tax risk as the dividend income will be taxed at 25 percent regardless of dividend payout size. Criticism ${ }^{23}$ of these tax consequences point out that passive investments rather than active are favored by lower tax uncertainty and that this may in turn affect access to capital for firms where (active) investors, that is, the employees, should face lower levels of asymmetric information. The

23 See, for example, Henreksson and Sanandaji (2014) 
Table 8: Differences between limited liability corporations and sole proprietorships ${ }^{24}$

\begin{tabular}{|c|c|c|}
\hline & Limited liability corporation & Sole proprietorship/Partnership \\
\hline $\begin{array}{l}\text { Economic division between firm } \\
\text { and owner }\end{array}$ & Yes & $\begin{array}{l}\text { No, (all) owner(s) liable for all } \\
\text { firm's debt and liabilities }\end{array}$ \\
\hline Lowest income tax & $\begin{array}{l}22 \% \text { corporate income tax }+20 \% \text { dividend } \\
\qquad \operatorname{tax}(\approx 37.6 \% \operatorname{tax})\end{array}$ & $30 \%$ (interest allocation) \\
\hline Highest income tax & $\begin{array}{l}56.99 \% \text { labor income tax, } 67.3 \% \text { including } \\
\text { social security contribution fees }\end{array}$ & $\begin{array}{l}56.99 \% \text { labor income tax } \\
66.71 \% \text { including social security } \\
\text { contribution fees }\end{array}$ \\
\hline Employed by & Firm & Self employed \\
\hline Can own securities in firm & Yes & No \\
\hline Social security contribution fee & $31.42 \%$ & $28.97 \%$ \\
\hline Minimum capital requirement & 50 O00 SEK & None \\
\hline $\begin{array}{l}\text { Interest on deposits to temporary } \\
\text { allocation of capital ("periodiser- } \\
\text { ingsfond") }\end{array}$ & Yes, maximum allocation of $25 \%$ of profit & $\begin{array}{c}\text { No, maximum allocation of } 30 \% \text { of } \\
\text { profit }\end{array}$ \\
\hline
\end{tabular}

severity of the tax uncertainty decreases for dividends paid out through the wage-based dividend allowance (löneunderlagsregel). If the minority owner reaches the highest marginal tax rate on income stemming from the specific company, he or she may use this allowance, which will then generally be large enough to include all of the dividend payouts to the owner. The dividend is then taxed at the 20 percent tax rate. That is, owners with high incomes from the company should still prefer to receive dividend payouts as active owners of the employing firm rather than as passive owners in an external firm.

In a classical corporate income tax system, profits are first taxed at the corporate level and then at the owner level. The income of an owner of a closely held firm thus faces "double taxation." If income is distributed as dividends or capital gains, the income is first taxed at the corporate level through corporate income tax and then taxed at the individual level at between 20 and approximately 57 percent. If income is distributed as wage, income is taxed as labor income and mandatory social security contributions. Wages and social security contribution fees, unlike dividends, are deductible at the firm level and thus lower the taxable corporate income.

The owner of a sole proprietorship, on the other hand, faces no corporate income tax. The income to the sole proprietorship is divided between capital income (with the

24 Other benefits with the sole proprietorships compared to the limited liability corporation are additional allocations of profits to special funds for income generated from forestry, damaged forests, and artistic performance or creative processes. regular capital income tax level at 30 percent) and wage income, which is taxed as labor income plus social security contributions (the contributions are slightly lower for sole proprietors than for employees or owners of closely held corporations). From a tax perspective, the return to capital is determined as an imputed return on the value of the equity invested in that firm, hereby referred to as the interest allocation (räntefördelning). Unlimited partnerships are taxed very similarly to sole proprietorships, with the major difference being that the return to capital is determined as the individual's relative ownership share of the unlimited partnership. Wage income is taxed individually for all partners as labor income. The general differences between limited liability corporations, on one hand, and sole proprietorships or unlimited partnerships, on the other hand, can be summarized as in Table 8 .

Overall, the size of the limited liability corporations, in terms of both turnover and tax payments, compared to sole proprietorships and unlimited partnerships may make the limited corporations more relevant to study from an economic perspective. However, the close connection between the firm in the sole proprietorships and the individual running the firm may generate opportunities for private consumption and under reporting of income, which may be considerable. By comparing grocery expenditures to reported income using Swedish data, Engström and Holmlund (2009) estimated that households with at least one self-employed under report total income by 30 percent and that self-employed in unincorporated businesses appear more likely to under report their income than those in incorporated businesses. The authors interpret these dif- 
Table 9: Tax error for different groups and type, billions of SEK, average 2001-2005.

\begin{tabular}{lcccc}
\hline & International & Undeclared work & Other error, national & Total tax error \\
\hline Individuals & 10 & 9 & 3 & 22 \\
Micro firms & 7 & 43 & 2 & 52 \\
SME & 14 & 5 & 7 & 26 \\
Large firms & 15 & 2 & 8 & 25 \\
Public sector & 1 & 1 & $<1$ & 2 \\
Not defined & - & 6 & - & 6 \\
$\quad$ Total & 46 & 66 & 20 & 133 \\
\hline Source: Swedish Tax Agency (2005) & & &
\end{tabular}

ferences as tax evasion entails higher costs for incorporated business activities.

The tax gap (skattefelet) may function as a blunt indicator of the magnitude of these problems. The tax gap estimates the difference between the correct tax that should have been paid if all business transactions would have been reported correctly and the estimated tax collected based on the information from income tax returns and controls (not the actual tax paid). Therefore, the tax gap includes both "deliberate" errors and unintentional errors.

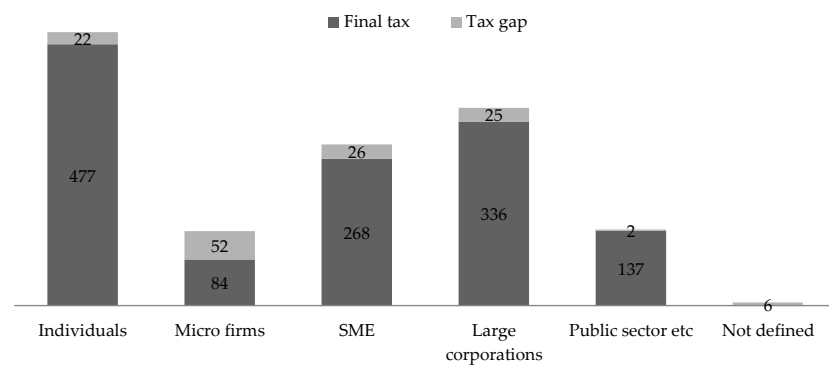

Source: Swedish Tax Agency (2005)

Figure 21: Tax gap: final and "correct" tax for different groups of tax payers, billions of SEK, average 2001-2005.

The tax gap is unproportionally large for the so-called micro firms; the Swedish Tax Agency reports that the data from 2001 to 2005 indicates that much of this error is likely due to shadow economy and undeclared work income. As seen in the following, most of the tax error for micro firms occurs within Sweden. However, for small and mediumsized enterprises (SMEs) and large corporations during the same period, the tax error mainly consisted of international tax planning of some type. Since then, the international tax planning has been given more attention in media. For legislators, tax base erosion and profit shifting have a negative effect on tax revenues. Governments have imposed several measures to decrease such tax rev- enue loss such as limiting the possibilities of tax planning through interest rate deductions. Corporate tax planning and recent policy reforms and current initiatives related to such are discussed in Section 3.

\subsection{Taxation of Wages versus Income from Sole Proprietorships or Closely Held Corporations}

We move on by discussing how the taxation of the different legal entities affects the incentives of someone who can channel his or her income through a company instead of as employed. When choosing whether to start a firm the individual generally considers starting a sole proprietorship/partnership or a closely held corporation (hereby referred to as $\mathrm{CHC}$ ). (See Table 8 for a summary of how these entities are taxed). For owners of both legal entity types, one difference as compared to ordinary wage earners is that firm owners can carry forward a share of the profit, whereas ordinary wage earners cannot sign a contract with their firm that shifts their labor income across time periods. As the marginal tax rate on labor income differs depending on labor income level, someone expecting to face a lower marginal tax rate in a future period can potentially reduce his or her tax by channeling income through a firm, instead of as being employed and carry forward part of the income. Next we consider the difference in taxation between channeling income as an ordinary wage earner or through (1) a sole proprietorship and (2) a CHC.

As described earlier, owners of a sole proprietorship are in principle taxed as usual wage earners, with the minor difference that social security contributions of ordinary wage earners are somewhat higher. Apart from the possibility of tax evasion and private consumption discussed earlier, the only clear tax benefit of starting a sole proprietorship as compared to a CHC is that one can then distribute income using the interest allocation from in- 
vested capital. Channeling income through a sole proprietorship instead of as wage decreases the effective tax wedge on what can be distributed within this allocation to only the capital income tax. The interest allocation is set as the government borrowing rate plus 6 percent multiplied by the capital within the firm. An owner of a sole proprietorship with 50000 SEK can use interest allocation on 3500 SEK, given a government borrowing rate of 1 percent. For someone facing the highest marginal tax rate on labor income, the corresponding tax difference is 1295 SEK $(=3500 \cdot(67 \%-30 \%))$. Most of those choosing whether or not to set up a firm will not have that much capital within the company. For these, the differences in tax treatment between channeling income through a sole proprietorship instead of as wage income will be negligible. By calculating the average tax rates of each quartile of the business income distribution, Edmark and Gordon (2012) found that owners in all quartiles would benefit from incorporating with 2007 year's rules. From a legal tax minimizing perspective, they concluded that those who can should in general incorporate. Controlling for several nontax factors, their estimate suggest that a one-percent increase in after tax income if $\mathrm{CHC}$ instead of non-corporate leads to a 0.75 percentage point increase in the chance that a firm is organized as a CHC. We focus the remainder of this section on CHCs.

Active, controlling owners in a $\mathrm{CHC}$ can choose the distribution of their incomes between wage and dividend income. As the Nordic countries have dual income tax systems and tax capital income separately from labor income and at a lower rate, the Nordic countries have implemented different versions of an income splitting system. For owners of closely held corporations, there are regulations in order to prevent income shifting between capital and labor. In Sweden, the taxation of dividends and capital income in closely held corporations is regulated through the so-called 3:12 rules. A company or an incorporated association (ekonomisk förening) qualify as a $\mathrm{CHC}$ when four or fewer individuals control more than half of the votes in the company, alternatively according to a subsidiary definition, where the business activity is divided into independent activities in which one person is in control. When defining the number of owners, all active owners and the immediate family of an active owner count as one.

The 3:12 rules only apply to dividends and capital income on qualified shares ${ }^{25}$ of a CHC. The purpose of the

25 A stock is considered as qualified if (1) the owner or someone within the close family have been active to a significant degree in the specific corporation during any of the preceding five years or in an- rules is to ascertain that incomes in a $\mathrm{CHC}$ that stem from the labor of the owner within the company should be taxed as labor income. The 3:12 rules impute a return on equity that constitutes an upper limit for how much of the firm's income an owner may distribute as capital income for tax purposes. Capital income in the form of dividends and capital gains within this dividend allowance is taxed at 20 percent. The allowance is calculated either through the so-called "simplification rule" (förenklingsregeln), under which a fixed amount ${ }^{26}$ is split among the owners of each CHC according to their ownership shares, or under the "general rule" (huvudregeln), which is based on the purchasing price of the shares and capital supplements plus wages paid to employees, including owners ${ }^{27}$. The general rule is generally chosen to calculate the allowance if the firm has a relatively large wage base or if the purchase price of the shares is high. Statistics Sweden's Firm Register and Individual Data Bases (FRIDA - Företagsregister och individdatabasen) shows that around 75 percent of active owners of CHCs have chosen the simplification rule during the period 2010-2012. Dividends above the dividend allowance but below an upper ceiling ${ }^{28}$ are taxed as labor income. What is not used of a years' dividend allowance is carried forward with an interest rate equal to the government borrowing rate plus 3 percentage points.

To understand how the current 3:12 rules affect the incentives to shift income, we target two main effects ${ }^{29}$. First, we discuss income shifting across tax bases for current owners of CHCs and evaluate how the incentives vary depending on the labor income level. Second, we consider the incentives to start a CHC or convert an existing business into a $\mathrm{CHC}$.

other CHC with similar business activity or (2) the CHC owns parts of another $\mathrm{CHC}$ which the owner has been active during the corresponding period.

26 The limit is 2.75 income base amounts, 156475 SEK in 2015.

27 To use wages paid to employees to calculate the dividend allowance under the general rule, the $\mathrm{CHC}$ owner also needs to have received a certain wage from the $\mathrm{CHC}$.

28 The upper ceiling is set at 90 income base amounts, 5229000 SEK in 2015.

29 Other effects on income shifting of the tax rules include for example effects on business structure. An example of such tax differences is that owner of a closely held corporation faces a 20 percent dividend tax, versus a 25 percent dividend tax if the corporation is instead classified as widely held. 


\subsubsection{Varying Incentives to Shift Income Depending on Labor Income Level - CHC owners}

The owner of qualified shares in a CHC can choose to distribute income within the company either as labor income or as dividends. Owing to the progressive labor income tax and the benefit entitlements associated with the mandatory social security contribution, the incentive to shift income varies depending on the level of labor income of the owner.

The social security contribution consists partly of different insurance and pension fees and partly of taxes. The statutory rate in 2015 is 31.42 percent. For the respective insurance fees, an increase in income is only associated with an increase in insurance entitlement up to certain labor income levels ${ }^{30}$. For incomes above a labor income ceiling, about 450000 SEK in 2015, increases in income do not lead to an increased insurance; hence, all of the social security contribution above that level should be seen as a tax. Figure 20 illustrates the marginal tax rate for the owner of a CHC depending on whether the income is distributed as wages (facing labor income tax and social security contributions), as dividends within the dividend allowance (facing corporate and capital income tax), or as dividends exceeding the dividend allowance (facing corporate and labor income tax). The marginal labor income tax rate includes the basic allowance, the municipal and state tax, and the earned income tax credit. How the earned income tax credit is gradually increased explains why the marginal tax rate facing wages increases already at low levels. If the income is distributed as wages, we include two post tax estimates because we do not know to which degree the individual values the benefits associated with the social security contribution. In the first measure, we consider the part of the contribution that does not have any insurance element as tax, "Wage - value of insurance." As the individual cannot opt out of the insurance components associated with the social security contribution, we also include a measure where all of the contribution is viewed upon as tax: "Wage - no value of insurance." The marginal tax rates in the graph only apply to standard CHC owners between 26 and 65, because those outside this age span face lower social security contributions.

To understand this graph, consider a CHC with one single owner who has not used up the dividend allowance. If this owner fully values the insurance, he or she

30 For a review in Swedish on the benefits associated with the social security contribution, see Flood et al. (2013). For a short summary in English, see Alstadsaeter and Jacob (2012).

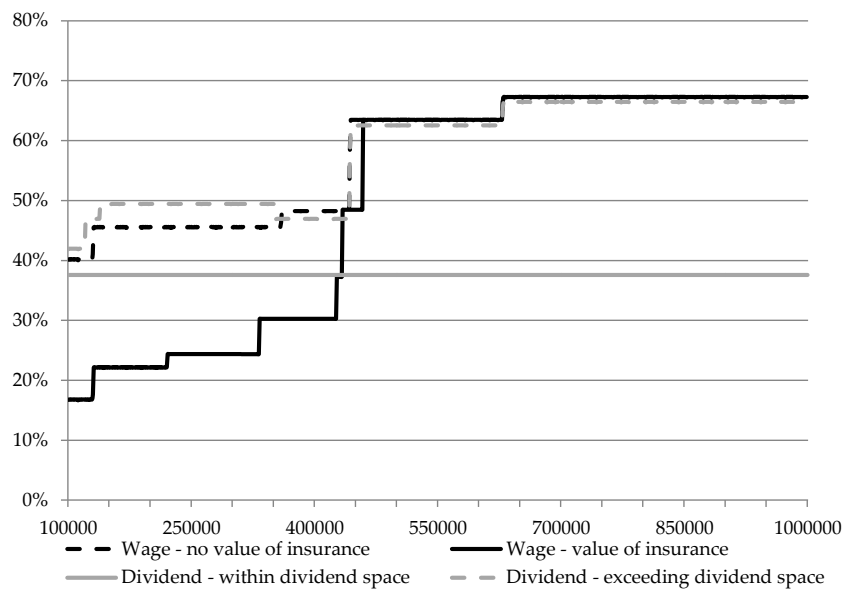

Source: Own calculations

Figure 22: Effective marginal tax rates for an owner of a $\mathrm{CHC}$ depending on how firm level income is distributed to the active owner, by level of initial labor income, 2014 rules.

should favor dividends once labor income exceeds about 430000 SEK. From the graph, we note that within the dividend allowance, any income shifting toward the capital income base will benefit those with higher labor income relatively more. At labor income levels above about $450000 \mathrm{SEK}$, the marginal tax rate on capital income is more than 20 percentage points lower than the tax on labor income. For incomes below about 430000 SEK, the owner should prefer to distribute the income as wages. We, therefore, expect particularly high income individuals to shift income through a CHC. It is worth noting that in the case of more than one active owner in a firm, determining the optimal amount of income shifting becomes more complicated. For dividends exceeding the dividend allowance, an individual who wants to maximize after-tax income should marginally favor dividends at income levels exceeding about 450000 SEK because the corporate income tax rate is lower than the social security contribution. Meanwhile at lower income levels, he or she should prefer to distribute income as wages because dividends, unlike wage income, do not qualify for the earned income tax credit.

Besides illustrating the income levels where it becomes optimal to shift income toward the capital base, the graph also illustrates how strong the incentive to shift income is at different labor income levels. That is, how much taxes the individual would avoid by shifting income toward the capital base. Moreover, it is straightforward to see that reductions in corporate income tax rates, as the one in 2013 from 26.3 to 22 percent decreases the marginal tax rates facing dividends - implicitly increasing the incentives to shift income toward capital. To which degree such 
shifting happens in turn depends on the economic system in general and how well the tax system is constructed to prevent such shifting.

The graph in Figure 22 shows that owners with higher labor income have a stronger incentive to distribute income as dividends and that this incentive is relatively strong already at income levels around 450000 SEK. In order to evaluate how these incentives translate into actual behavior, Figure 23 provides descriptive evidence regarding which single-owned CHCs that distributed dividends in $2013^{31}$. The likelihood of a single-owned CHC to distribute dividends increases with the labor market income of the owner. This increase is particularly significant at incomes between 350000 and 450000 SEK. For incomes around 550000 SEK, where the marginal tax rate on wage income is around 63 percent, the owners are almost twice as likely to have dividends from the $\mathrm{CHC}$ than at income levels around 350000 SEK, where the corresponding marginal tax rate is about 30 percent for someone who fully values the entitlements associated with the social security contribution. In line with these results, Alstadsaeter and Jacob (2012) also found that CHC owners with wage income but no dividend income from CHCs have labor incomes below the threshold for state income tax.

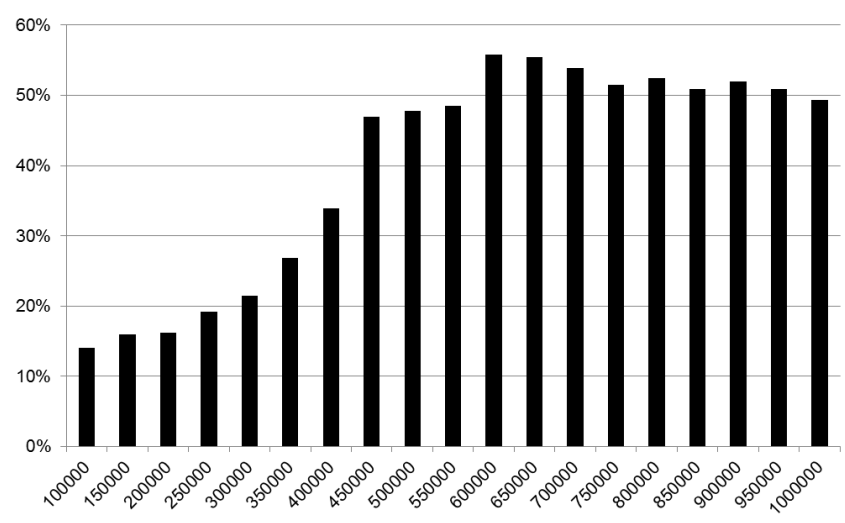

Source: Own estimations using FRIDA (Företagsregister och individdatabas)

Figure 23: Share of single-owned CHCs that distribute dividends exceeding 10000 SEK depending on labor market income among 27- to 64-year olds, 2013 outcomes.

Figure 23 merely provides indicative evidence on the effects of the 3:12 rules on income shifting. To discuss the causal effects of the 3:12 rules on income shifting we turn to the 2006 reform. For a thorough empirical evaluation of

31 The tax brackets were only marginally changed between 2013 and 2014, which rules Figure 20 was based on. the effects of this reform on income shifting, see Alstadsaeter and Jacob (2012). This reform implied a tax cut estimated at the time to about 1 billion SEK on owners of qualified shares in CHCs. The 2006 reform reduced the tax rate on dividends within the dividend allowance from 30 to 20 percent $^{32}$. In Figure 22, this implies that the marginal tax rate on dividends within the dividend allowance was shifted downwards. Moreover, the amount of dividend allowance increased substantially via changing the general rule ${ }^{33}$ and via introducing the simplification rule. In line with that the reform made it more beneficial for those with a high income to own a CHC and channel income through dividends, Alstadsaeter and Jacob (2012) showed that the total income increased more among active $\mathrm{CHC}$ owners than among other tax payers (+ 68272 SEK) and that this difference mainly derived from higher dividends using a difference-in-difference strategy on the 2000-2009 period.

\subsubsection{Shifting Income via Starting or Reclassifying as a $\mathrm{CHC}$}

The number of CHCs has increased since the 2006 reform. Slemrod (1995) and Gordon and Slemrod (2000) emphasized that what might appear as a sign of real effects of taxes, such as shifts in legal organization, might be income shifting across tax bases solely to minimize firm owners' tax payments. We focus on two reasons why starting a CHC or getting reclassified as a $\mathrm{CHC}$ can be beneficial:

1. Those who are not yet active can possibly lower their future tax payments by setting up a $\mathrm{CHC}$ to accumulate dividend allowance since these can be carried forward with interest. The accumulated dividend allowance then represents an option where the value of the option stems from the tax wedge between future labor and capital income tax rates.

2. Owners of holding corporations (corporations where most income is financial) can reduce their effective dividend tax from 25 to 20 percent within the dividend allowance via reclassifying as a $\mathrm{CHC}$.

For illustrative purposes of the payoffs of setting up a CHC, consider a person who is evaluating whether or not to set up a company in which he or she will have future

32 The reform also consisted of the abolishment of a small, tax free dividend allowance ("lättnadsbeloppet").

33 The dividend allowance arising from wages to employees increased from about 12 percent of the wage sum to about 20 percent for wage sums below 60 income base amounts and 50 percent of the wages exceeding this threshold. 
profits realized in 2, 5, or 10 years, respectively. Setting up a CHC implies that the individual has to invest at minimum 50000 SEK. Return on capital allocated in a company faces a corporate income tax (22 percent) and a dividend tax (20 percent) which add up to an effective tax rate of 37.6 percent, which is higher than the capital income tax, 30 percent. The difference between these two represents the tax wedge. Assuming that the individual invests the minimum required equity, the annual alternative cost of having the capital locked within the company instead of invested in another project that is only taxed at the individual level is given by the tax wedge times the minimum investment times the gross return. As of 2011, smaller equity companies no longer have compulsory audits (revisionsplikt). We assume annual administrative time costs of running the company to be 2000 SEK per year and a fixed startup cost of 5000 SEK. Assuming that the discount rate, $r$, equals the gross return, the discounted costs can be summarized as

$$
\begin{aligned}
& N P V(C H C \text { costs })= \\
& =5000+\sum_{t=0}^{T} \frac{2000+r(37.6 \%-30 \%) \cdot 50000}{(1+r)^{t}}
\end{aligned}
$$

For simplicity, we consider a CHC that does not pay out wages. We thereby assume that the owner will choose the simplification rule when determining the annual dividend allowance. To calculate the accumulated dividend allowance, we assume that the dividend allowance will be constant at 2014 year's values and that these are carried forward with an annual interest of 5 percent. Thereby the size of the accumulated dividend allowance, ADA, is about 491000 SEK in 2 years, 1059000 SEK in 5 years, and 2211000 SEK in 10 years. For simplicity, we assume that the owner is certain to be taxed at the highest labor income tax rate if the profit is distributed as labor income. Thereby having income taxed as dividends at 37.6 percent (combined corporate and capital income tax rate) instead of as labor income at 67.3 percent (combined payroll and labor income tax rate) for incomes distributed as dividends within the dividend allowance implies that the tax savings are approximately 30 percent of the pre-tax income. For incomes exceeding the dividend allowance, the corresponding savings from distributing income as dividends is approximately 1 percent.

$$
\begin{aligned}
& N P V(\text { CHC income })= \\
& =\frac{30 \% \cdot \text { Income } \leq A D A+1 \% \cdot \text { Income }>A D A}{(1+r)^{T}}
\end{aligned}
$$

Figure 24 illustrates the net present value of starting up the $\mathrm{CHC}$ via illustrating the total payoff depending on income realized for the three different respective time horizons.

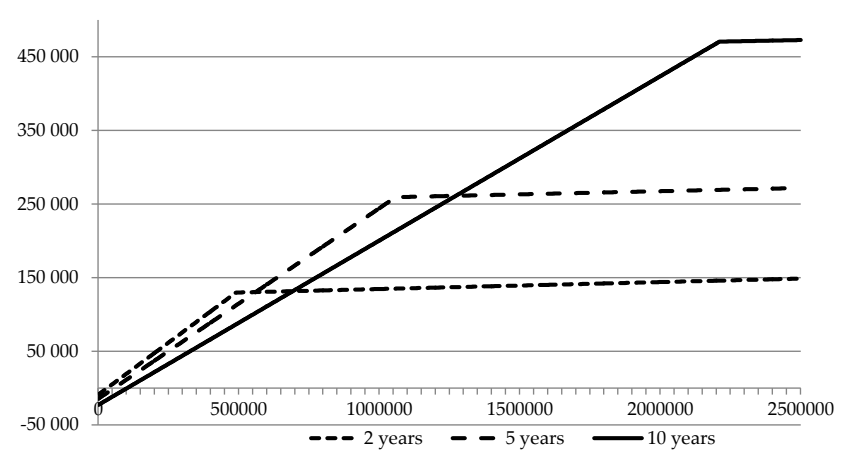

Figure 24: Net present value of setting up a $\mathrm{CHC}$ depending on profit generated in 2, 5, or 10 years, illustrative example using 2014 rules.

Naturally, if the project does not generate income, it has a negative payoff. The critical observation is that the individual should find it optimal to start a $\mathrm{CHC}$ already at very low levels of expected future income that can be channeled through a CHC. Moreover, the potential gains from starting such a company are clearly significant and increases with the planning horizon.

There are of course several nontax reasons for setting up a CHC which might end up having low activity or for setting up a holding company. The former might be used to channel minor income from business activity, whereas the latter might simplify the ownership structure when several partners co-own share of subsidiaries. In order to shed some lights on how these two strategies are used in practice, we briefly present some evidence from Alstadsaeter and Jacob (2012). Prior to the introduction of the simplification rule in 2006, the owner needed to have a large acquisition value or a large wage sum within a firm, that is, real business activity in order to get a significant dividend allowance. Thereby, the option value of starting a CHC without activity was very low. For owners of holding companies, the incentive was to not be classified as a CHC up until 2006. After the reform getting classified as a CHC instead of a widely held company implied a tax reduction from 25 to 20 percent on capital gains for holding companies; hence, the incentive was now to be classified as a CHC. Based on the results presented in Figure 25, from Alstadsaeter and Jacob (2012), we note that out of new $\mathrm{CHCs}$, the share shell corporations ${ }^{34}$ increased from

34 The authors define a shell corporation as not being a holding corporation AND no turnover over sample period AND average wage bill below SEK 100000 over sample period. 
about 2 percent to about 5 percent following the reform. The corresponding increase for holding companies was from averaging less than 10 percent before reform 20022005, to over 20 percent in 2006, and about 15 percent in 2007 and 2008. To further illustrate that this pattern might stem from income shifting, the authors note that the average labor income among the ones with firms classified as low turnover jumps up after the reform to exactly the level where individuals face the state tax and can hence benefit from a tax wedge.

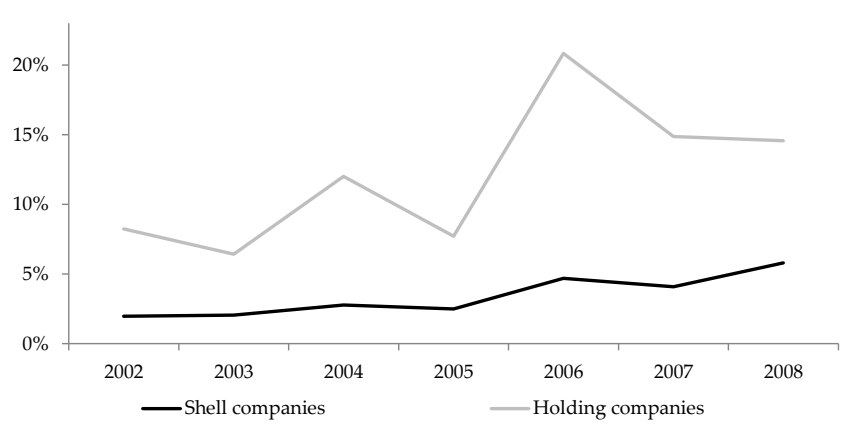

Source: Graph from Figure 4.9 page 144 Panel B, in Alstadsaeter and Jacob (2012)

Figure 25: Share out of new CHCs that are classified as shell companies and holding companies.

While the dividend allowance creates an option value for an individual deciding whether or not to set up a firm, the unused dividend allowance represents a potential tax loss for the policy-maker. Alstadsaeter and Jacob (2012) noted that the accumulated unused dividend allowances increased from 135 billion SEK in 2005 to 345 billion SEK in 2009. By 2012, the accumulated dividend allowance has reached 639 billion $\mathrm{SEK}^{35}$. However, the potential tax loss realized up to date is significantly smaller, because the major source of growth for dividend allowance is that the yearly allowances in many cases exceed the distributed profits in the firms. In 2012, the new dividend allowance was 203 billion SEK, whereas only 55 billion SEK was used to distribute dividends and capital gains.

Other incentives for income shifting associated with the 3:12 rules that are not thoroughly discussed here, for example, concentrating the ownership in order to simplify the optimization of the amount of income to be distributed as dividends. For an exceptionally good overview of the tax incentives created by the 3:12 rules, see Alstadsaeter and Jacob (2012).

35 Own calculations for 2012

\subsection{Recent Reforms and the Current Agenda}

\subsubsection{The 2006 Reform and Recent Changes of the 3:12 rules}

Based on the investigation by Edin et al. (2005), the government proposed changes in the 3:12 rules at the end of 2005, Swedish Government (2005/06:40). The main purpose of this reform was to stimulate business activity and increase investments and employments in corporations with concentrated ownership. Since then, the 3:12 rules have been modified in 2007, 2008, 2009, 2012, and 2014. These later changes have in general made the system more generous toward owners. The legislator has also continuously updated the rules in order to avoid potential misusage. The 2014 year's reform is a good example of the latter. Prior to the reform, the 3:12 rules implied that owners who had very small ownership shares in corporations with a large wage base (löneunderlag) had been able to channel large amounts of income as dividends. In the budget bill for 2014, it was noted that this could harm the legitimacy of the 3:12 rules and that these owners had received too much compensation. As a result, the rules were changed, and an owner can now only get a dividend allowance from the wages paid to employees according to the general rule if he or she owns at least 4 percent of the shares in the CHC. The increased tax revenues from this tightening of the rules were spent on increasing the dividend allowance for other firms classified as CHCs and increasing the amount of interest allocation for sole proprietors, such that the reform package was revenue neutral.

Presently, there is a committee that is supposed to finish their investigation by 1 September 2016. The investigation should look more closely at the 3:12 rules in general and suggest how these can be altered to limit the possibilities for income shifting. The directives (Fi. 2014:06 directive 2015:2) mention that the tension between labor and capital income has changed since 1990. It also acknowledges the crucial role of the 3:12 rules for the incentive to start up and run companies. The committee should as examples analyze suitable changes in the size of the dividend allowance according to the simplification rule, the requirements for using the simplification rule, the determination of return to capital for tax purposes, the size of the wage component in the general rule and the requirements to get to use that wage base when calculating the dividend allowance, the rules regarding the saved dividend allowance, the ceiling rules on what is taxed as capital versus labor income, and the tax rate on dividends within the allowance and above the ceiling. 


\subsubsection{Corporate Tax Planning}

The objective of international tax planning is basically to decrease a corporation's income tax. This can be done by shifting income from high-tax jurisdictions to low-tax jurisdictions. In general, the higher the effective corporate income tax rate is in a given jurisdiction, the higher the incentive to reduce a company's income in this jurisdiction by tax income shifting. Income can be shifted by charging inflated prices on transactions between related parties or by using interest payments on internal loans. The general trend for corporate income tax (CIT) in the OECD countries has been a decrease in the tax rate over time. In many cases, decreases in the tax rate have been combined with broadening of tax bases. Sweden has since the large tax reform in 1990-1991 decreased the CIT to 28 percent (1993), then 26.3 percent (2009) and since January 1, 2013, to 22 percent. The most recent decrease in the CIT was partially financed by limiting the tax deductibility of interest payments on intercompany loans. Yet, the World Bank's "Doing Business" indicator estimates the effective tax level on corporate profits to be around 13.4 percent in Sweden in 2015, which is well below both the CIT rate of 22 percent and also below the average effective tax rate in the OECD countries. Given that the World Bank estimate is accurate, the low effective tax rate is partially explained by that the Swedish depreciations rules are rather generous. The real effect of the combined changes in CIT level and the restrictions on interest deductions on tax planning by Swedish corporations have yet to be evaluated. However, and as already mentioned, one possible short-term effect from lowering the CIT was that some companies may have shifted income from fiscal year 2012 to fiscal year 2013. Technically, this can be done by firms increasing the amount set off to the tax allocation reserve ${ }^{36}$. As a result, the corporations could defer their profits from being taxed at 26.3 percent and instead being taxed at the new CIT level of 22 percent. It is likely that some part of the corporate tax base was shifted from 2012 to later periods. This may have allowed some corporations to profit from the cut in the corporate income tax rate somewhat earlier.

Other countries such as Germany and Japan have also decreased the CIT rate over the past decade, lowering the average CIT level in OECD. Currently, Sweden maintains a corporate income tax level below the OECD average, but several countries have signaled cuts in the tax rate. When lowering the corporate income tax level, several OECD countries have also limited the possibilities for tax planning, broadening the tax base, and, therefore, maintaining a [relatively] stable level of corporate income tax revenue as a share of gross domestic product (GDP) over time. The revenue from the corporate income tax is, however, one of the most volatile and is very sensitive to economic growth.

While the corporate income tax level has been decreasing, attention to tax base erosion because of tax planning has increased significantly over time. Information through media reports on large international corporations paying virtually no or very small amounts of tax have become more common. Recently, media reports on tax rulings involving large international corporations have received substantial attention. The official CIT have sometimes been decreased substantially by tax rulings. Some of the corporations mentioned in the reports have Swedish headquarters and are under Swedish corporate income law. To limit tax base erosion, several countries have taken measures to decrease the possibilities for tax planning by limiting interest deductions. Also, cooperation on tax treaties between countries has increased, thus decreasing the possibilities for tax rulings. The ongoing project "Base erosion and profit shifting", short BEPS, in the OECD have been initiated by the G20 countries to equip governments with the domestic and international instruments needed to address the challenges of aggressive tax planning.

In 2009 and 2013, the possibilities for interest deductions on internal debt were reduced. The goal was to reduce possibilities to shift profits to affiliate firms located in countries with no or low corporate income taxes. The typical case described for this type of tax planning is a group of affiliate corporations with one parent company abroad, which owns, directly or indirectly, a Swedish-based corporation. The group of corporations strives to decrease the corporate income tax for the Swedish corporation. Therefore, the group of companies aims at reallocate the corporate income from the Swedish corporation to another, non-Swedish-based corporation abroad in another country with lower (or no) corporate income tax, while keeping the profit within the group of corporations.

In 2014, the Swedish Committee on Corporate Taxation ${ }^{37}$ proposed further limitations to interest deductions. The main proposal is the so-called CBIT (comprehensive business income tax), where no deductions are allowed for net interest expenses on a consolidated firm group level. This is combined with a tax cut where only 75 percent of

37 Företagsskattekommittén (SOU 2014:40)
36 The Swedish tax system allows firms to allocate up to 25 percent of their taxable earnings to a tax allocation reserve. 
corporate income is subject to corporate income tax ${ }^{38}$. As a consequence, the effective CIT decreases from 22 percent to 16.5 percent. As interest on debt financing is deductible in the current Swedish corporate tax system while dividends paid on equity financing is not, removing deductions for net interest expense effectively creates neutrality in the tax treatment of debt and equity financing. In terms of neutrality between different types of legal forms and the suggested changes, unlimited partnerships would be affected by the limitations of interest rate deductions but because they do not pay CIT, they would not enjoy the benefit of a decreased tax rate. Sole proprietorships are not affected by the proposed changes. As of date, the suggestions from the Swedish Committee on Corporate Taxation have been scrutinized by stakeholders with various levels of positive and negative reactions. In short, the suggestions are less beneficial for highly leveraged sectors such as the property sector, while low leverage sectors such as the service sector with stable profits would gain from the suggested changes.

While sole proprietorships are not affected by the proposals of the Swedish Committee on Corporate taxation, another committee, "Skatteförenklingsutredningen" proposed changes in their taxation in October 2014. The committee suggests substantial changes in the sole proprietorships' possibilities of temporary allocation of income and the calculation of the return to firm capital. In some terms, the suggestions aim for increased neutrality between different legal forms, while other suggestions by the committee risk decreasing the neutrality. One of the major suggestions presented by the committee is to replace the different types of possible capital allocations available to sole proprietorships and partnerships with only one type of capital allocation. The report and the proposals therein have also been scrutinized by stakeholders and the reactions are mixed.

\subsection{Concluding Remarks}

The Swedish tax system aims for tax neutrality across legal type. Similar to other Nordic countries, incomes in Sweden are taxed differently depending on whether they are considered as capital or labor incomes. As distinguishing between these two sources of income can be hard, tax neutrality across legal entities in turn becomes harder to

38 A secondary alternative suggests limiting net interest deductions at 20 percent of EBIT, and compensating this by lowering the corporate income tax so that the reform is revenue neutral. achieve. As a consequence, business incomes are taxed somewhat differently depending on legal entity.

Combining a progressive labor income tax with a flat relatively low capital income tax rate also creates incentives to channel income through companies instead of as ordinary wage. Above, we showed that from a legal tax avoidance perspective channeling the income through a CHC should in general be preferred over using a sole proprietorship. Moreover, the incentives to channel income through a CHCare stronger for those with higher labor market earnings. To which degree these tax incentives feed into income shifting from labor to capital income is difficult to assess. The Swedish income splitting rules, the 3:12 rules, are continuously modified to balance the two goals of creating an economic environment that stimulates business activity, while avoiding income shifting.

\section{Bibliography}

Alstadsaeter, Annette and Martin Jacob. 2012. Income Shifting in Sweden - An empirical evaluation of the 3:12 rules. Report to the Expert Group on Public Economics 2012:4. Stockholm: Ministry of Finance.

Edin, Per-Olof, Ingemar Hansson and Sven-Olof Lodin. 2005. Reformerad ägarbeskattning - effektivitet, prevention, legitimitet. Stockholm: Ministry of Finance.

Edmark, Karin and Roger Gordon. 2012. "Appendix III: Taxes and the Choice of Organizational Form by Swedish Business Owners." In Income Shifting in Sweden: An Empirical Evaluation of the 3:12 Rules. Report to the Expert Group on Public Economics 2012:4 edited by Annette Alstadsaeter and Martin Jacob. Stockholm: Ministry of Finance.

Engström, Per, and Bertil Holmlund. 2009. "Tax evasion and selfemployment in a high-tax country: evidence from Sweden." Applied Economics, 41 (19): 2419-2430.

Flood, Lennart, Katarina Nordblom and Daniel Waldenström. 2013. Konjunkturrådets rapport 2013 Dags för enkla skatter. Stockholm: SNS förlag.

Firm Register and Individual Data Bases (FRIDA), Statistics Sweden, 2015.

Gordon, Roger and Joel Slemrod. 2000. “Are “real” responses to taxes simply income shifting between corporate and personal tax base" In Does Atlas shrug? The economic consequences of taxing the rich, edited by Joel Slemrod, 240-279. Cambridge: Harvard University Press.

Swedish Government. 2005. "Reformerade beskattningsregler för ägare i fåmansföretag." Government Bill 2005/06:40.

Henrekson, Magnus and Tino Sanandaji. 2014. Företagandets förutsättningar - en ESO-rapport om den svenska ägarbeskattningen, Rapport till Expertgruppen för studier i offentlig ekonomi 2014:3. Stockholm: Ministry of Finance.

Företagsskattekommittén. 2014. "Neutral bolagsskatt - för ökad effektivitet och stabilitet" SOU 2014:40, Statens offentliga utredningar. 
Slemrod, Joel. 1995. "Income creation or income shifting? Behavioral responses to the tax reform act of 1986." American Economic Review Papers and Proceedings, 85 (2): 175-180.
Swedish Tax Agency. 2005. "Skattefelet - vad är skattefelet”. Swedish Tax Agency. 2014. "Skattestatistisk årsbok 2014". 